\title{
Okuma Üzerine Sanat Temelli Boylamsal Bir Araştırma: İlkokul Öğrencileri Okurken Nasıl Hissediyor?
}

\author{
An Art-Based Longitudinal Study on Reading: How Do Primary-School Children \\ Feel While Reading?
}

\author{
Hülya Kartal* ve Dilek Bilhan**
}

$\ddot{O}_{z}$

Amaç: Yaşam boyu okuyucu olup olmamanın önemli göstergelerinden biri okumaya karşı olumlu ve olumsuz duygular hisseden ögrencilerin algl ve duygularıdır. Bu araştırma, ilkokul ögrencilerinin okurken nasil hissettikleri ve aradan iki yll geçtikten sonra bu duygulardaki değişim ve gelişimin belirlenmesinin amaçlandı̆̆ boylamsal bir araştırmadır. Yöntem: Araştırma çalışmanın amacı doğrultusunda nitel araştırma yaklaşımlarından biri olan fenomenoloji (olgu bilim) desenine göre ve araştırma verilerinin toplanması bakımından ise gelişimsel araştırma yöntemine göre yürütülmüş̧ür. Araştırmanın çalışma grubunu Bursa'ya bağll Inegöl ilçe merkezindeki bir ilkokulda öğrenim gören 126 öğrenci oluşturmaktadır. Araştırma verileri, araştırmacılar tarafindan hazırlanan "Kitap okurken neler hissettiğini veya nasıl hissettiğini bir resim çizerek gösterir misin?” açık uçlu sorusuna yönelik ögrencilerin ikinci ve dördüncü sinıfta yapmış olduğu çizimler aracılı̆̆ıyla toplanmıştır. Araştırma verileri 2016-2017 ve 2018-2019 eğitim öğretim yıllarının bahar yartyılında toplanmıştır. Araştırma verileri analizi, çizimin ana konusunun "okuryazarlık" olduğu çizimlerde, evrensel olan duygusal yüz ifadeleri ve duygularl yansitan sembol, işaret, sözcük ve duygusal ifadeler doğrultusunda kodlanarak ve bu kodlamalara dayalı frekansların hesaplanmasıyla yapılmıştır. Bulgular: Araştırma bulgularına göre, ögrencilerin büyük çoğunluğu hem ikinci hem de dördüncü sinıftayken okurken olumlu duygular hissetmekte; ikinci sinıftayken ögrencilerin sadece altısı dördüncü sınıftayken ise on ikisi okurken "farklı duygular” hissetmekte; kız ögrenciler erkek öğrencilere göre hem ikinci hem de dördüncü sinıftayken duygularını ifade ederken "kalp" figürlerine daha fazla yer vermekte; hem kiz hem de erkek öğrencilerin yaklaşık olarak yarısı hem ikinci sınıfta hem de dördüncü sinıfta okurken hissettiklerine yönelik duygu durumlarını ifade ederken çizimlerinde açık kitap figürlerine yer vermekte; düşünme ve konuşma baloncuğu figürlerine yer vermeleri bakımından sınıf düzeylerine göre farklılık bulunmakta ve ögrenciler okudukları veya okumak

\footnotetext{
* Bursa Uludağ Üniversitesi, Eğitim Fakültesi Temel Eğitim Bölümü, Bursa, Türkiye. E-posta: hkartal@uludag.edu.tr

Bursa Uludag University, Faculty of Education Primary Education Department, Bursa, Turkey. E-mail: hkartal@uludag.edu.tr

** Bursa Uludağ Üniversitesi, Eğitim Fakültesi Güzel Sanatlar Eğitim Bölümü, Bursa, Türkiye. E-posta: dbilhan@uludag.edu.tr

Bursa Uludag University, Faculty of Education, Fine Arts Education Department, Bursa, Turkey. E-mail: dbilhanl@uludag.edu.tr
}

Geliş Tarihi - Received: 23.04.2021

Kabul Tarihi - Accepted: 29.06.2021

Yayımlanma Tarihi - Published: 30.06.2021 
istedikleri eserlerin isimlerine hem ikinci hem de dördüncü sinıfta çizimlerinde yer vermektedir. Sonuç: Araştırma sonuçları, sınıf düzeyi ilerledikçe ilkokul öğrencilerinin okurken hissettikleri duyguların olumlu yönde devam ettiğini başka bir ifadeyle ilkokul ögrencilerinin okumaya dair olumlu duygular beslediklerini göstermektedir. Ö̈günlük: Illkokul çağındaki çocukları ve onların deneyimlerini, duygularını ve iç seslerini anlamaya yönelik bir yaklaşım, onları resim çizmeye davet etmektir. Okuma becerilerine yönelik araştırmalar söz konusu olduğunda ön plana çıkan veya merak edilen boyutun okurun duygularının değil okumanın bilişsel velya akademik boyutunun olduğu ve araştırmaların çoğunlukla nicel verilere dayandı̆̆ görülmektedir. Ancak ilkokul ögrencilerinin okurken hissettikleri duyguların çizimler aracılığıyla ortaya konulduğu herhangi bir çalışmaya ise ulaşılamamıştır.

Anahtar Sözcükler: Boylamsal araştırma; duyguların ifadesi; okumaya dair duyguların gelişimi; sanat temelli araştırma; ilkokul öğrencileri.

\section{Abstract}

Objective: One of the crucial indicators of being a reader throughout life is the positive and negative perceptions and feelings developed towards reading in childhood. This longitudinal research aims to determine how elementary-school children feel while reading and how they express their feelings through drawings. Moreover, the research intended to determine whether their feelings towards reading changed and developed after two years. Method: In accordance with the purpose of the study, the research was designed as a phenomenology method and conducted within the developmental research method according to the collected data. The research was carried out with 126 children from the second and fourth grade in an primary school in Inegol, one of the districts of the city Bursa and continued during the 20162017 and 2018-2019 academic years. According to an open-ended question prepared by the researchers; "Can you draw a picture about how you feel while reading a book?", the research data were collected through children's drawings. The drawings listed under the main theme "literacy" were coded within the typical facial expressions, and symbols, signs, words reflecting the emotional expressions and analyzed through calculating the frequencies based on these encodings of the drawings. Results: According to the findings, the vast majority of the children in the second grade and then also later in the fourth grade have positive feelings while reading. In the second grade, only six children and in the fourth-grade twelfth children stated that they have "different feelings" while reading. Girls drew "heart" images more than the boys when expressing their feelings in both the second and fourth grades. It was determined that approximately half of the boys and girls drew "open book" images while expressing their feelings on their readings in the second and fourth grade. There are differences according to grade levels in terms of drawing "thinking and speech bubble" images, and interestingly, in the second grade and following the fourth grade, the children wrote the names of their favourite books they have read or wanted to read in their drawings. Implications: These results show that as the grades progresses, the positive emotions of the primary-school children continue throughout their school years; in other words, children nurture positive feelings about reading. Originality: One approach to understanding primary-school children and their experiences, feelings and inner voices is to invite them to draw pictures. When it has been discussed about the researches related to the reading 
skills, it is seen that the dimension that comes to the fore is not the emotions of reader but the cognitive or academic dimension of reading and the studies are mostly based on quantitative data. However no study has been found in which the feelings of primary school students' while reading are revealed through drawings.

Keywords: Longitudinal study; expression of feelings; development of feelings towards reading; art-based research, primary children.

\section{Giriş}

Okuma becerisi çok önemli bir eğitim hedefidir (Birleşmiş Milletler Eğitim, Bilim ve Kültür Örgütü [UNESCO], 2011, s.17). Okumak yeni firsatlar yaratmanın yanı sıra yeni bilgiler edinmemizi, edebiyattan keyif almamızı ve modern yaşamın parçası olan günlük şeyleri yapmamızı sağlar (Ward ve Shortt, 2013, s. 444). Öğrenme entelektüel olduğu kadar duygusal da bir deneyimdir (Brown, 2000, s. 275). Ne yazık ki UNESCO'nun 2017 y1lı verileri yaklaşık 750 milyon insanın hala okuyup yazamadığını ve 250 milyon çocuğun da küresel olarak gerekli okuryazarlık becerilerini edinemediğini göstermektedir (Valentin ve Casipit, 2019, s. 59). Bireyin okumaktan zevk alabilmesi için bireyde okumaya dair olumlu duygular oluşturulmasına gereksinim vardır. Bu duygular da yaşantı ve deneyimler sonucu oluşur. Bruckerhoff (1977, s. 104), kırk yıl önce "çocukların okuma konusunda iyi duygular geliştirmelerine yardımcı olmak için neler yapılabilir?” şeklinde bir soru sormuş. Bu sorunun sorulması, araştırmanın yapıldığı dönemde de çocukların okuma konusundaki duygularının merak edildiğini göstermektedir. Günümüzde bu durumda bir değişiklik olmuş mudur? Bir değişiklik olduysa bu hangi yöndedir? Bu çalışmada tam olarak bu soruya yanıt aranmaya çalışılmıştır: Çocuklar okurken nasıl hissediyorlar ve hissettikleri sınıf düzeyi ilerledikçe farklılık gösteriyor mu? Çevreyi, insanları ve etraftaki yerleri görme, duyma, dokunma ve tepki verme şeklimizi etkileyen duygular, günlük yaşamımızın ayrılmaz bir parçasıdır (Milligan, 2005, s. 2105). Arnold ve Whitehurst, çocuğa kitap okunmasının duygusal yönlerini vurgulayarak bu süreçte okuma sevgisini arttırmanın okuma-yazma öncesi becerileri geliştirmekten daha önemli olduğunu belirtmiştir (Baker, Scher ve Mackler, 1997, s. 124). Sonraki basamakta çocukların okuma ve yazma ile ilgili duygu ve isteklerinin, ilkokulda okuma ve yazma öğrenmedeki ilerlemeleri ile ilgili olabileceği düşünülmektedir (Francis, 1997, s. 5). Yaratma ve merak1 tatmin etmenin bir yolu olarak nitelendirilen (Causey, 1955, s. 58-65) okumadan zevk alma, okuma ilgisi, okuryazarlığın doğası ve işlevlerinin iyi anlaşılması gelişme ile bağlantılıyken, kaygı ve yanlış anlama ise okumada yavaş gelişme ile bağlantılıdır (Francis, 1997, s. 5). Araştırma sonuçları çocukların okuryazarlık deneyimlerini eğlenceli etkileşimlerle ilişkilendirdiklerinde okumaya olumlu bakacaklarını göstermektedir (Daisey, 1991; Wigfield ve Asher, 1984 aktaran Baker, Scher ve Mackler, 1997, s. 124).

Okuma ve yazmayı öğrenmek, çocukların başarı veya başarısızlı̆̆ında, eğitsel bağlamda, can alıcı bir önem taşımaktadır (Mata, Mackaaij ve Calado, 2020, s. 322). Öyle ki çocukların okuma ve yazmayla ilgili duygu ve isteklerinin ilkokulda okuma ve yazmayı öğrenmedeki ilerlemeleri ile ilgili olduğu düşünülmektedir. (Francis, 1997, s. 6). Bu da okumaya dair duyguların çocukların okuma isteklerine doğrudan olumlu ya da olumsuz yönde etki edebileceğini göstermektedir. Bu yönleriyle bireyin özellikle de yaşam boyu okur olup olmamasında okurken hissettiklerinin belirleyici bir rolünün olduğuna inanılmaktadır. 
Nitekim araştırma sonuçları okumaya karşı olumlu ve olumsuz duygular hisseden öğrencilerin algı ve duygularının yaşam boyu okuyucu olup olmamalarının önemli göstergelerinden biri olduğunu göstermektedir (Zambo, 2006, s.798). Şöyle ki okumayı seven çocuklar hem okumaktan keyif almakta hem de ilk firsatta okumaya zaman ayırmakta ve kendilerini iyi okurlar olarak görmektedir. Diğer taraftan okumayı sevmeyen çocuklar ise okumaktan keyif almamakta bunun sonucu olarak okumaktan olabildiğince kaçınmakta, okumayı bir tehdit olarak görmekte ve okuma zamanı geldiğinde endişelenmektedir (Zambo, 2006, s.799).

Okumak konusunda yapılan araştırmalar incelendiğinde bunların çoğunlukla okumanın bilişsel ve/ya akademik boyutunda yoğunlaştığı (Zaccoletti, Altoè ve Mason, 2020, s. 2) ve nicel verilere dayandığı görülmektedir. Konu hakkında yapılan araştırmalara dair en çok atıf yapılan çalışmalar arasında okuma becerileri, okuma edinimi, okuduğunu anlama, okuduğunu anlama stratejileri, okuma akıcılığı, okuma başarısı, okuma motivasyonu, okumaya yönelik tutum ve okuma alışkanlığı başlıklarının olduğu görülmüştür. Öyle ki “okuma becerileri”" konusunda en çok atıf alan (3893-877) üç çalışmadan ilki "3893” atıf ile Perfetti'nin (1985) çalışmasıdır. Bunu "2258” atıf ile Cunningham ve Stanovich (1997) ve "2130" atıf ile Harris (1956)'in yaptığı çalışmalar izlemektedir. Okuma edinimi konusunda sirasiyla Ziegler ve Goswami (2005), Share (1995), Cunningham ve Stanovich (1997)'in çalışmaları en çok atıf alırken; okuma başarısı konusunda en çok Baker ve Wigfield (1999; 1518); Carlisle ve Feldman (1995; 1106) ve Hallinger, Bickman ve Davis (1996; 1089)'in çalışmaları atıf almıştır. Okuma akıcılığına yönelik yapılan çalışmaların arasında sırasıyla Stanovich (1980; 2868); Fuchs, D.Fuchs, Hosp ve Jenkins (2001; 2075) ve Chard, Vaughn ve Tyler (2002; 1028)'ın çalışmalarının en çok atıf aldığı; okuduğunu anlama konusundaki çalışmalar arasında en çok atıf yapılanlar (2250-751) incelendiğinde sırayla Duke ve Pearson (2009; 2250), Snow (2002; 2703) ve Pearson ve Gallagher (1983; 1950)'in çalışmalarının olduğu belirlenmiştir. Okuduğunu anlama stratejileri konusunda en çok atıf alan (1275-807) üç çalışmanın Gersten, Fuchs, Williams ve Baker (2001; 1275); Coiro ve Dobler (2007; 1102); Pressley, El-Dinary, Gaskins, Schuder, Bergman, Almasi ve Brown (1992; 807)'nın çalışmaları olduğu belirlenmiştir. Okuma motivasyonu konusunda yapılan çalışmalar arasında en çok atıf yapılan (2095-769) üç çalışmadan ilki Wigfield ve Guthrie (1997; 2095)'nin; ikincisi Gambrell (1996; 937)'in ve üçüncüsü de Wang ve Guthrie (2004; 769)'nin çalışmasıdır. Okumaya yönelik tutum konusunda yapılan çalışmalar arasında en çok atıf alan (1921-612) üç çalışma sırasıyla Sherif, M.Sherif ve Nebergall (1965; 1921); McKenna, Kear, ve Ellsworth (1995; 1453); Baker, Scher ve Mackler (1997; 612)'in çalışmalarıdır. Okuma alışkanlığı konusunda en çok atıf yapılan (477-292) çalışmaların üçü ise Applegate ve M.D.Applegate (2004; 474); Hughes-Hassell ve Rodge (2007; 364); Clark ve Foster (2005; 294)'ın gerçekleştirdiği çalışmalardır.

Okumaya yönelik duyguların açığa çıkarılması amacıyla yürütülen bir araştırmada (Zambo, 2006, s.801). 3-6.sınıf öğrencilerinin okuma algıları ve okumaya dair hissettiklerini belirlemek için düşünce balonu resimlerini kullanmıştır. Araştırma sonucunda öğrencilerin okumaya dair pozitif ve negatif duygular beslediği belirlenmiştir. Başka bir çalışmada 1999 yılında "çocukların okuryazarlık hakkında görsel imgeleri var mı?” (McKay ve Kendrick, 1999, s. 8) sorusuyla yola çıkan araştırmacılar, çocukların okuryazarlık imgelerini dört yıl sonra (Kendrick ve McKay, 2003, s.2) tekrar incelemiştir. Bu süreçte araştırmacılar, 
çocukların çok zengin okuryazarlık imgelerinin olmasının yanı sıra çizimlerinin okuryazarlığın çok yönlü ve etkileşimli doğası hakkında karmaşık anlayışları ortaya çıkardığını keşfetmiştir. Dahası, okuryazarlıkla ilgili olarak çocukların çizimlerinde kendilerini ve diğerlerini nasıl algıladıkları açıkça görülmüştür.

Yukarıda belirtilen çalışmalardan hiçbirinde doğrudan okurken hissedilen duygulara dair bir araştırma bulunmamaktadır. Başka bir ifadeyle okuma araştırmaları söz konusu olduğunda ön plana çıkan veya merak edilen boyutun okurun duygularının olmadığ düşünülmektedir. Oysaki birçok araştırmada özellikle de okuma alışkanlığı, okuma motivasyonu ve tutumunda duyguların doğrudan olumlu veya olumsuz etki ettiği belirtilmektedir. Bununla birlikte Pekrun (2014, s. 8) öğrenme süreçlerinde duyguların rolü üzerine yapılan çalışmalarda bir miktar artış olduğunu ve öğrenme bağlamlarında duyguların önemli rolünü dikkate almak gerektiğini belirtmiştir. Çocuklar ve deneyimleri hakkında bilgi edinmenin bir yolu, çocukları resim yapmaya davet etmektir (Dockett ve Perry, 2005, s. 81). $\mathrm{Bu}$ çalışma ilkokul öğrencilerinin okurken nasıl hissettiklerinin yani okuma eylemi esnasındaki duyguların öğrenci çizimleri aracılığıyla doğrudan ortaya çıkarılması bakımından hem ulusal hem de uluslararası alanyazından farklılık göstermektedir. Ulusal alanyazında konuya yönelik olarak bu yaklaşımla bir araştırma yapılmadığı belirlenmiştir. Uluslararası alanyazında ise çizimlerin analizine dayalı olarak ilkokul düzeyinde farklı yaş grupları ve sınıf seviyelerindeki öğrencilerin okuryazarlık deneyimleri (Negi, 2015, s. 204), okur deneyimleri (Ganasi, 2010, s. 25) ve "okur" olarak hissettiklerini (Zambo, 2006, s. 800) belirlemeye yönelik araştırmalar yer almaktadır. Ancak ilkokul öğrencilerinin okurken hissettikleri duyguların çizimler aracılığıyla ortaya konulduğu herhangi bir çalışmaya ulaşılamamıştır.

Kendrick ve McKay (2004, s. 115) küçük çocukların çizim ve diğer sembol sistemleri yoluyla okuryazarlık bilgilerini ve deneyimlerini nasıl temsil ettiklerine odaklanan gelecekteki araştırmaların, çocukların okuryazarlık gelişiminin dinamik ve evrimsel doğası hakkında daha geniş bir perspektif sağlama potansiyellerinin olduğunu belirtmektedir. Araştırmacıların yürüttükleri çalışmadaki çizimler, çocukların okuryazarlığının "anlık görüntüleri" ile sınırlıdır. Uzun bir süre boyunca bir dizi görüntü toplamayı içeren karşılaştırmalı bir çalışma ile farklı geçmişlerden gelen dil öğrencilerinin kendilerini nasıl temsil ettikleri ve zaman ve mekandaki okuma yazma deneyimlerinin ortaya konulabileceğini düşünmektedirler. Mevcut çalışmada, ilkokul öğrencilerinin okurken nasıl hissettikleri ve aradan iki yıl geçtikten sonra bu duygulardaki değişim ve gelişimin boylamsal olarak belirlenmesi amaçlanmıştır. Bu nedenle araştırmaya katılan ilkokul ikinci sınıf öğrencileriyle, iki yıl sonra onlar dördüncü sınıfa geldiklerinde tekrar çalışılmıştır.

\section{Yöntem}

\section{Araştırma Deseni}

Nitel araştırma, çoklu öznel veri türleri ve kendi doğal ortamında belirli durumlardaki bireylerin incelenmesine dayanan yorumsamacı araştırma yaklaşımıdır (Denzin ve Lincoln, 1994 aktaran Christensen, Johnson ve Turner, 2015, s. 54). Bu araştırmada, ilkokul öğrencilerinin okurken nasıl hissettikleri ve bu duyguların yıllara göre değişiminin belirlenmesi amaçlandığı için araştırma nitel araştırma yaklaşımlarından biri olan 
fenomenoloji (olgu bilim) desenine göre yürütülmüştür. Fenomenoloji, fenomenleri ve onun bireyler tarafından nasıl algılandığını ve deneyimlendiğini keşfetmektir (Lester, 1999, s. 2). Patton'a (2018, s. 104) göre fenomenolojik ve fenografik yaklaşımların ortak olarak paylaştıkları şey, insanların deneyimi "nasıl” anlamlandırdığını ve hem bireysel olarak hem de paylaşılan anlam olarak deneyimi bilince "nasıll" dönüştürdüklerini keşfetme üzerine odaklanılmasıdır. Deneyim kavramı, fenomenoloji alanında temel taş olarak görülmektedir. Husserl (1969) fenomenolojide, deneyimin düşünsel ve materyal olmak üzere iki boyutu olduğunu varsaymaktadır (aktaran Aydın Günbatar, 2019, s. 296). Deneyimin düşünsel boyutunu, noesis ve noema olmak üzere birbiriyle alakalı iki kısım oluşturmaktadır. Noesis, bir olguyu algılama, düşünme veya hissetme yani deneyimleme boyutudur. Noema ise bir olgunun deneyimlenmesi sırasında kişide bıraktığı alg1, his, düşünce veya yargıdır. $\mathrm{Bu}$ araştırmanın odağında öğrencilerin kitap okuma deneyimleri ve bu deneyimlerde neler hissettikleri veya nasıl hissettiklerinin belirlenmesinin olması nedeniyle fenomenolojik araştırmanın düşünsel boyutunu yansitmaktadır.

Araştırma verilerinin toplanması bakımından ise nitel araştırma yaklaşımına dayalı araştırma yöntemlerinden biri olan gelişimsel araştırma yöntemine göre yürütülmüştür (Şahin Çakır, 2019, s. 344). Araştırmacılar çalışmalarında ya farklı yaş gruplarındaki, kültürlerdeki bireylerin ya da aynı bireylerin yaşamlarının farklı zamanlarındaki duygu, düşünce, davranış vb. değişimlerini ve gelişimlerini incelemek amacıyla gelişimsel araştırma yöntemlerini uygulamaktadırlar (Şahin Çakır, 2019, s. 344). Odak noktası insan gelişimi olan gelişimsel araştırma türlerinden biri de boylamsal araştırmalardır. Boylamsal araştırmalar, bir süre boyunca özellikle de insanın gelişimi ile ilgili olarak yürütülen uzunlamasına araştırmalardır ve bu araştırmalarda aynı örneklem üzerinde farklı zaman dilimlerinde ölçümler yapılmaktadır. Bu nedenle bu çalışmalar "takip" çalışmaları olarak da ifade edilmektedir. Mevcut çalışma da ilkokul öğrencilerinin okurken hissettikleri duygulara dair zaman içindeki değişim ve gelişimin araştırıldığı boylamsal bir araştırmadır.

\section{Araştırma Grubu}

Araştırma, Bursa'ya bağlı İnegöl ilçe merkezindeki Vehbi Koç İlkokulu’nda yürütülmüştür. Okuma becerileri yönünden okuma hızı ve okuduğunu anlama düzeyleri açısından belli bir düzeye geldikleri için okurken nasıl hissettiklerini değerlendirebilecek deneyimleri olması nedeniyle araştırmanın ilk grubunda ilkokul ikinci sınıf öğrencileriyle çalışılmıştır. Bu süreçte okul idaresinin öğretmenleri bilgilendirmesiyle, 2016-2017 eğitim-öğretim yılının bahar yarıyılında araştırmaya katılmak konusunda gönüllü olan sınıf öğretmenlerinin olduğu sınıflardaki öğrencilerle çalışılmıştır. Bu sınıflar okuldaki on bir şubeden 2C-D-G-K-L-M şubeleridir. Araştırmaya ikinci sınıfta altı şubeden 172 öğrenci katılırken dördüncü sınıfta bu öğrencilerden 126'sına ulaşılmıştır. Şubeler düzeyinde 2C şubesinden yedi öğrenci (C-2-3-1016-21-22-23), 2D şubesinden sekiz öğrenci (D-1-3-5-14-16-17-18-22), 2G şubesinden sekiz öğrenci (G-3-7-9-10-14-24-26-28), 2K şubesinden dört öğrenci (K-1-4-7-17), 2L şubesinden beş öğrenci (L-8-14-18-20-26) ve 2M şubesinden ise 14 öğrenciye (M-1-5-6-8-9-10-11-1320-21-23-26-27-28) dördüncü sınıfta ulaşılamamıştır. Ulaşılamayan öğrencilerin büyük çoğunluğu okul değiştirmiş, birkaç öğrenci ise o gün okula gelmemiştir. 4.sınıf öğrencilerine 
2018-2019 eğitim-öğretim yılının bahar yarıyılında ulaşılmıştır. Aşağıdaki tabloda araştırma grubuna ilişkin bilgiler yer almaktadır.

Tablo 1

Araştırmaya katılan ögrencilerin sınıf düzeyi ve şubelerine göre dă̆ılımı

\begin{tabular}{crrr}
\hline Şube & $\begin{array}{r}\text { İkinci sınıfta araştırmaya } \\
\text { katılan öğrenci sayısı }\end{array}$ & $\begin{array}{r}\text { Dördüncü sınıfta } \\
\text { araştırmaya katılan } \\
\text { ögrenci sayısı }\end{array}$ & $\begin{array}{r}\text { Takip araştırmasında yer } \\
\text { almayan öğrenci sayısı }\end{array}$ \\
\hline C & 24 & 7 \\
D & 31 & 14 & 8 \\
G & 22 & 26 & 8 \\
K & 34 & 25 & 4 \\
L & 29 & 21 & 5 \\
M & 26 & 16 & 14 \\
Toplam & 30 & $\mathbf{1 2 6}$ & $\mathbf{4 6}$ \\
\hline
\end{tabular}

\section{Veri Toplama Aracı}

Kearney ve Hyle (2004, s. 362)'nin araştırmalarında katılımcıların çizimlerinden yararlanma nedenlerinden biri, araştırma tasarımının ayrılmaz bir parçası olan çocuk çizimlerinin katılımcıların yapılandırılmamış görüşmelerde deneyimlerini herhangi bir sınır koymadan ifade edebilmelerinde bir katalizör olmasıdır. $\mathrm{Bu}$ araştırmada öğrencilerle herhangi bir görüşme yapılmamıştır. Ancak her iki veri toplama sürecinde de katılımcılardan "okurken kendilerini nasıl hissettikleri”nin resmini çizmeleri istenmiştir.

Nitel veri, kelimelerden, resimlerden, elbiselerden, belgelerden veya diğer sayısal olmayan bilgilerden oluşur (Christensen, Johnson ve Turner, 2015, s. 54). Araştırma verileri araştırmacılardan biri tarafından hazırlanan öğrencilerin çizimine dayalı bir soru ve dört açık uçlu sorudan oluşmaktadır. Araştırmada öğrencilerin çizim yoluyla yanıtlamalarına dayalı soru, Clark, Osborne ve Akerman'ın (2008, s. 52) "Gençlerin okur olarak algıları (Young people's self-perceptions as readers) isimli araştırmada yer alan sorulardan birinden hareketle "Okumanın sizin için nasıl bir his olduğuna dair bir resim çizer misiniz? (would you draw a picture about how reading feels for you?)" hareketle şu şekilde hazırlanmıştır: "Kitap okurken neler hissettiğini veya nasıl hissettiğini bir resim çizerek gösterir misin?” Bu soruyla birlikte "En çok severek okuduğun üç kitap hangileridir?", "Bu kitapları okumayı neden sevdin?, "Okumayı hiç sevmediğin veya çok az sevdiğin üç kitap hangileridir?”, "Bu kitapları okumayı neden sevmedin?" soruları sorulmuştur. Araştırmanın ilk sorusuna dair sonuçlar boylamsal olarak ele alınması nedeniyle, diğer araştırma sorularından elde edilen sonuçlara bu çalışmada yer verilememiştir.

\section{Geçerlik ve Güvenirlik}

Araştırmanın yöntem bölümü başlı̆̆ 1 altında, araştırma deseninden araştırma grubuna, veri toplama aracından veri toplama süreci ve analizine kadar tüm basamaklardaki işleyişe yönelik yapılan ayrıntılı açıklamalar mevcut araştırmanın geçerliğini artırmıştır. Nitel araştırmaların güçlü yanlarından biri olan geçerlik, okuyucu, katılımcı ve araştırmacının bakış açısından bulguların doğru olup olmadığının belirlenmesine dayanmaktadır (Creswell ve Miller, 2000 
aktaran Creswell, 2017, s. 201). Bunların yanı sıra araştırmanın güvenirliği Yin'in (2009) belirttiği gibi araştırmacılar olarak sürecin tüm basamakları yazılı olarak kayı altına alınarak sağlanmaya çalışılmıştır (aktaran Creswell, 2017, s. 201). Ayrıca ister nicel ister nitel yöntemler olsun araştırmaların çeşitli yöntem ve verilerle yürütülmesi başka bir ifade ile üçgenleme yöntemini izlenmesi araştırmaları güçlü kılan yollardan biri olarak gösterilmektedir (Patton, 2018, s. 247). Bu çalışmada araştırma verilerinin ikişer y1l arayla aynı araştırma grubundan toplanması ve araştırma verilerinin hem okuma-yazma alanı hem de sanat alanından iki uzman tarafından analiz edilmesiyle üçgenleme yöntemi uygulamaya geçirilerek araştırmanın daha güçlü kılınması amaçlanmıştır.

\section{Veri Toplama Süreci}

Araştırma verileri iki aşamada toplanmıştır. Birinci aşamada, 2016-2017 eğitim-öğretim yılının bahar yarıyılında ilkokul ikinci sınıflar ile çalışılmıştır. Bu süreçte araştırma verileri, araştırmacılardan birinin danışmanlığını yürüttüğü bir lisansüstü öğrencisi aracıllğıyla toplanmıştır. Bu lisansüstü öğrenci, aynı zamanda araştırmanın yürütüldüğü okulda birinci sınıf düzeyinde sınıf öğretmeni olarak görev yapmaktadır. Bu yönüyle öğrenciler tarafından tanınan bir öğretmendir. Araştırma verileri, her sınıfta sınıf öğretmeninin uygun gördüğü derste bir ders saatinde toplanmıştır. Araştırma hakkında, öğretmen tarafından açıklama yapılmıştır. Bu veri toplama süreci bir hafta sürmüştür. İkinci aşamada 2018-2019 eğitimöğretim yılının bahar yarıyılında yine aynı öğrencilerle dördüncü sınıftayken çalışılmıştır. Bu veri toplama süreci araştırmacılardan biri tarafından yürütülmüştür. Araş̧ırmacı ilk verilerin toplandığ1 altı şubeye öğretmenlerin uygun gördüğü saatlerde giderek ve araştırma hakkında açıklama yaparak her bir sınıfta bir ders saati olmak üzere altı ders saatinde verileri toplamıştır. Araştırma ve önceki uygulama hakkında öğrenciler bilgilendirildiğinde, bu durumun öğrencilerin çok ilgisini çektiği görülmüştür. Bu süreçte kimi öğrenciler, ek süreye gereksinim duyduğu için teneffüs zamanında da veri toplama uygulaması devam etmiştir. Veri toplama sürecinde kimi öğretmenler, sinıfta kalarak öğrencilerini gözlemlemeyi tercih etmiş ancak sürece herhangi bir şekilde müdahale etmemişlerdir. Ayrıca öğrencilerin sürece katılım konusunda son derece istekli davrandıkları gözlenmiş̧tir.

\section{Veri Analizi}

Nitel verilerin toplanması sırasında ve toplandıktan sonra araştırmacı devamlı olarak verileri katılımcıların öznel bakış açılarından anlamaya çalışır (Christensen, Johnson ve Turner, 2015, sayfa 54). Çok küçük çocuklar, insanların ne hissettiğini kolaylıkla anlayabilir çünkü duygular genellikle yüzlerinde görünür. Bebeklerin ilk dikkatli gözlemcilerinden biri olan Charles Darwin bu sonuca varmıştır (Harris, 1989, s. 5). "İnsan ve Hayvanlarda Duyguların İfadesi”" isimli klasik eserinde Darwin (1872), çeşitli ulusların yüz ifadelerindeki benzerlikten etkilenmiştir. $\mathrm{Bu}$ benzerliklerde, duygusal ifadelerimizin doğuştan, evrensel bir temeli olduğunu savunmuş ve bu basit, cesur hipotez, duygu ve duygusal gelişim üzerine güncel araştırmalara ilham vermeye devam etmektedir. Hiatt, Campos ve Emde'nin (1979, s. 1021) araştırma sonuçları da Darwin'in bu hipotezini doğrular niteliktedir. En azından üzüntü/acı, mutluluk ve öfkenin yüz ifadelerinden anlaşıldığı konusunda bir uzlaşmaya varılmıştır. Bu noktada hem yetişkinlerle hem de bir yaşından daha küçük bebeklerle yapılan çalışmalarda, 
duygular ve yüz ifadeleri hakkında net sonuçlara ulaşılmıştır. Şöyle ki yetişkinlerin katıldığı araştırmada, katılımcıların dinledikleri duygusal içerikli öyküler sonucunda \%92'sinin mutluluk, \%84'ünün öfke, \%81'inin iğrenme ve \%79'unun da üzüntü yüz ifadelerinin olduğu fotoğrafları seçtiği belirlenmiştir. Ayrıca bir yaşından küçük bebeklerin altı farklı durumla karşı karşıya bırakıldığı araştırmada, bebeklerin yetişkinlerde olduğu gibi gülümsediği ve göz kapaklarının altında kırışıklıklar belirdiği görülmüştür (Harris, 1989, s. 11). Bunların yanı sıra iki temel olumsuz duygudan biri olan üzüntü/acı (diğeri öfke) hakkında, yüzdeki üzüntü ifadesi için bebeklerde aşılanma anı izlenmiştir (Izard, Hembree, Doughery and Spizzirri, 1983 aktaran Harris, 1989 s. 12). Bu esnada gözlerin sıkıca kapatıldığı, böylece gözlerinin etrafındaki derinin kırıştığı ve kaşların çatıldığı gözlenmiştir. Ayrıca ağzın geniş bir şekilde açıldığı ve dudakların kendine özgü bir şekilde geri çekildiği ve bunun da diş etlerinin veya dişlerin az çok açığa çıkmasına neden olarak kare şeklinde bir form almasına neden olduğu görülmüş̧ür. Benzer şekilde TenHouten (2017, s. 7) da yine Darwin'in aynı eserine ve duyguların anlaşılmasına yönelik sayısız kültürlerarası araştırmaya atıf yaparak Darwin (1872)'in derin evrimsel kökenleri nedeniyle insanlar arasında kültürden bağımsız olarak neşe, korku ve öfke gibi en yalın/basit duygulara dair yüz ifadelerinin ortak olduğunu ileri sürdüğünü belirtmiştir. $\mathrm{Bu}$ iki kaynak arasında bir duygunun ifade edilişi bakımından farklılıklar olduğu görülse de (Örneğin "happiness” sözcüğünün “joy” şeklinde ifade edilmesi) birleştikleri ortak nokta, birincil duyguların keyif/neşe/mutluluk, korkma/korku ve öfke olmasıdır.

Yukarıda belirtilen araştırma sonuçlarına dayanarak mevcut araştırmada öğrencilerin çizimlerinin analizinde şöyle bir yol izlenmiştir:

1. Öğrencilerin “okurken nasıl hissetikleri”ni belirleyebilmek amacıyla öncelikle çizimlerdeki yüz ifadeleri ve bu yüz ifadelerindeki duygular anlaşılmaya çalışılmıştır. Kendrick ve McKay (2002, s. 45), çocukların çizimleriyle okuryazarlık anlatılarını ortaya çıkarmak amacıyla gerçekleştirdikleri araştırmada "Teorik çerçeve ve çizimlerin analiz yönteminin sanat eğitmenleri ve gelişim psikologlarından farklı” olduğunu belirtmişlerdir. Bizim çalışmamızda ise çizimlerin analizleri sanat eğitimi alanında bir araştırmacı ve okuma-yazma becerileri alanında lisans ve lisansüstü dersler yürüten ve bu konuda araştırmalar yapan bir araştırmacı tarafından yapılmıştır. Yüz ifadelerine dair değerlendirmeler, sanat eğitimi alanı uzmanı olan araştırmacı tarafindan Brechet, Picard ve Baldy (2007, s. 147), Brechet, Bady ve Picard (2009, s. 897) ve Zambo (2006, s. 800-801)'nun kodlama sistemindeki kategorileri de kapsayan bir yaklaşımla yapılmıştır. Nitekim Zambo, analizlerde çizimlerdeki yüz ifadelerinde öncelikle herhangi bir fiziksel veya duygusal ipucu olup olmadığına bakılması gerektiğini belirtmiştir. Bu inceleme her iki araştırmacı tarafından birkaç defa yapılmıştır. Araştırmacıların hangi duygu ifadesi olduğuna dair tereddüt ettikleri çizimlere dair değerlendirmeler Covid-19 salgını nedeniyle "Google meeting” aracılığıyla yapılan görüşmelerde tartışılmıştır. Bu tartışmalar sonucu, duygu ifadelerine karar verilmiştir.

2. Çocukların çizimleri Kendrick ve McKay (2003, s. 1)'in çalışması doğrultusunda üç kategoriye ayrılmıştır: Birinci kategoride, çizimin ana konusunun "okuryazarlık" olduğu çizimler (örneğin, kitap okuyan, hikâye ve mektup yazan veya alfabeyi öğreten bir kişinin resmi) bulunmaktadır. İkinci kategoride, okuryazarlık eserlerinin veya olaylarının çizimin "eklenti" bileşenleri olduğu çizimler (örneğin, ağırlıklı olarak bir sayfanın köşesindeki bir 
kitabın küçük bir taslağı) bulunmaktadır. Üçüncü kategoride ise genel olarak okuma ve yazma ile veya dil öğrenimi ile ilgili görünmeyen çizimler (Örn. Spor/tif ekipmanlar/1 veya hayvanlar). Bu kategorilerden sadece birinci kategoride yer alan yani çizimin ana konusunun okuryazarlık olduğu çizimlere ait çözümlemelere yer verilmiştir. Bunun en temel nedeni, katılımcı çizimlerinin iki yıl arayla iki kez toplanması ve bu verilerin analizinden çocukların okurken hissettiklerine dair çok sayıda ve çeşitlilikte araştırma bulgusuna ulaşılmasıdır.

3. Öğrencilerin çizimlerinde okumanın temel kaynağı olan "kitap" olsa da olmasa da Zambo (2006, s. 801)'nın da belirttiği gibi “duygu”yu yansıtan herhangi bir yüz ifadesi veya sembol (Örn., kalpler, barış işaretleri, göz yaşları), işaret/belirti/ (Örn., gülen yüz, kitaptaki karakterlerin resimleri), sözcük/ler (Örn., kolay, eğlenceli, gerçekten ilginç, kafası karışmış, zor, kötü) duygusal ifadeler (Örneğin, "Seviyorum/hoşlanıyorum/beğeniyorum", "iyi hissettiriyor", "nefret ediyorum", "üzgün") doğrudan duygu göstergesi olarak kabul edilmiştir. Ayrıca Zambo (2006, s.801)'nun araştırmasında merkezde “düşünme balonları (thought bubbles)" yer almaktadır. Mevcut araştırmanın merkezinde ise "öğrencilerin okurken nasıl hissettiklerini çizmeleri" bulunmaktadır. Araştırma yazarlarından sanat alanında uzman olan yazar tarafından öğrenci çizimlerinde "duyguları” yansıtan tüm elemanlar kodlanmıştır.

4. $\mathrm{Bu}$ kategorilendirmelerin sonunda araştırma verilerinin analizleri şu başlıklar altında toplanmıştır: a. Çizimlerde "keyif/neşe/mutluluk" duygularının gösterildiği durumlar b. Çizimlerde farklı duyguların bir arada gösterildiği durumlar c. Çizimlerde duyguların "kalp" figürleriyle gösterildiği durumlar d. Çizimlerde duyguların "kitap" figürleriyle gösterildiği ve/ya desteklendiği durumlar e. Çizimlerde duyguların "düşünme balonları”yla gösterildiği ve/ya desteklendiği durumlar f. Çizimlerde duyguların "konuşma balonları”yla gösterildiği ve/ya desteklendiği durumlar g. Çizimlerde duyguların "kitap ve/ya yazar isimleri”yle gösterildiği ve/ya desteklendiği durumlar. Aşağıda duygu durumlarını gösteren çizim örnekleri yer almaktadır.

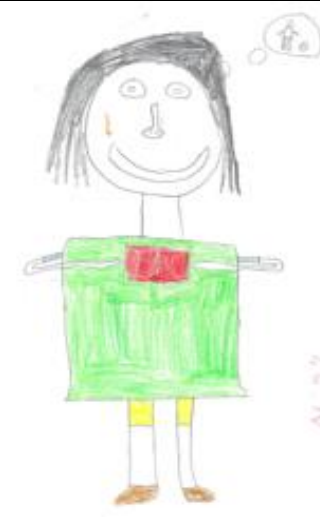

Resim 1. Mutlu

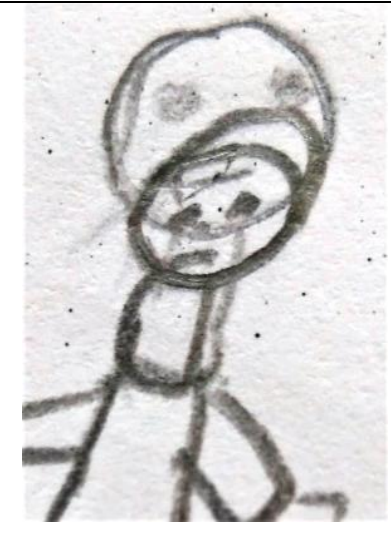

Resim 2. Üzgün

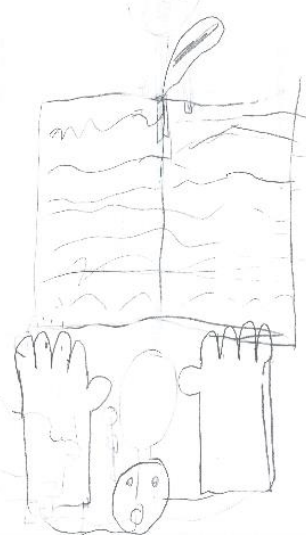

Resim 3. Şaşkıın

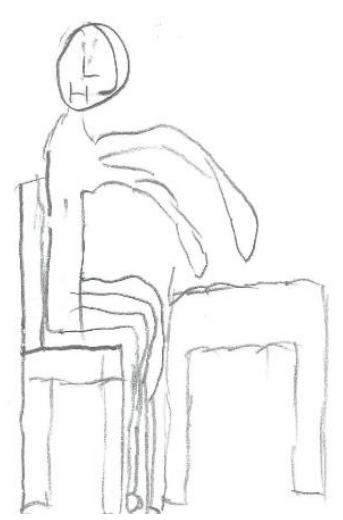

Resim 4. Nötr

\section{Bulgular}

$\mathrm{Bu}$ araştırmada, öğrencilerin okurken nasıl hissettiklerini belirlemek için iki yıl arayla onların resim yapmalarını istedik. Bu amaçla doğrudan sadece çocukların çizimlerine dayanarak çocukların okurken hissettiklerinin yani duygularının analizini yaptık. Bu analizlerde, çocukların ikinci ve dördüncü sınıftaki duygularını karşılaştırdık. İlkokul ikinci sınıf 
öğrencilerinin okurken hangi duyguları hissettiğini ve bu duyguların dördüncü sınıfa geldiklerinde değişip değişmediğini inceledik. Analiz sonuçları, ikinci sınıfta $58 \mathrm{kız}$ ve 41 erkek öğrencinin dördüncü sınıfta da yine buna çok yakın değerlerde olmak üzere 54 kız ve 41 erkek öğrencinin okurken olumlu duygular hissettiklerini diğer bir ifadeyle çocukların okurken mutlu, keyifli, neşeli, sevinçli olduklarını göstermektedir. Ne ikinci sınıfta ne de dördüncü sınıftayken katılımcıların çizimlerinde sadece "üzüntü” duygusunu yansıtan yüz ifadeleri bulunmamaktadır. Bu nedenle tabloda veri analizindeki başlıklardan "üzgün-mutsuz" yüz kodu ve bu kod altındaki başlıklara yer verilmemiştir. Diğer taraftan araştırmaya katılan 126 öğrenciden ikinci sınıftayken sadece 1 öğrencinin dördüncü sınıftayken de yine sadece 1 öğrencinin okurken olumsuz duygular hissettiği belirlenmiştir. Bu öğrenciler ikinci sınıfta bir kız öğrenciyken (konuşma baloncukları) dördüncü sınıfta ise bir erkek öğrencidir (düşünce baloncukları). Bu sonuçlar, ikinci sınıf öğrencisinin duygularının dördüncü sınıfta olumlu yönde; dördüncü sınıf öğrencisinin ise olumsuz yönde değiştiğini göstermektedir.

Tablo 2

Çizimlerde duygu durumlarını ortaya koyan doğrudan göstergelerin dağılımı

\begin{tabular}{|c|c|c|c|c|}
\hline \multirow[b]{2}{*}{ Kod } & \multicolumn{2}{|c|}{ Íkinci Sınıf } & \multicolumn{2}{|c|}{ Dördüncü Sınıf } \\
\hline & $K ı(f)$ & $\operatorname{Erkek}(f)$ & $K \boldsymbol{K u}(f)$ & $\operatorname{Erkek}(f)$ \\
\hline \multicolumn{5}{|l|}{ Keyifli-Neşeli-Sevinçli-Mutlu Yüz } \\
\hline A ğız-dudak yukarı kıvrımlı & 46 & 36 & 36 & 23 \\
\hline Ağız yarı açık ve yukarı kıvrımlı & 3 & 4 & 3 & 3 \\
\hline Ağız çok açık ve yukarı kıvrımlı & 7 & - & 10 & 7 \\
\hline Ağız açık yukarı kıvrımlı ve dişler görünmekte & - & - & 1 & - \\
\hline Ağız çok açık ve dişler bütünüyle görünmekte & 2 & 1 & - & 7 \\
\hline Ağız açık ya da yukarı kıvrımlı, dil dışa ve sağa & - & - & 4 & 1 \\
\hline \multicolumn{5}{|l|}{ ya da sola doğru kaydırılmış görünmekte } \\
\hline $\begin{aligned} \text { Toplam } \\
\end{aligned}$ & 58 & 41 & 54 & 41 \\
\hline $\begin{array}{l}\text { Farklı duygu durumlarının bir arada ifade } \\
\text { edildiği }\end{array}$ & 4 & 2 & 7 & 5 \\
\hline \multicolumn{5}{|l|}{ Bir kalp figürü } \\
\hline Büyük kalp figürü & 6 & 3 & 8 & 3 \\
\hline Küçük kalp figürü & 3 & - & 2 & - \\
\hline \multicolumn{5}{|l|}{ Birden fazla kalp figürü } \\
\hline Büyük kalp figürleri & 10 & 5 & 3 & 1 \\
\hline Küçük kalp figürleri & 9 & 3 & 7 & 2 \\
\hline Toplam & 28 & 11 & 20 & 6 \\
\hline \multicolumn{5}{|l|}{ Kitap } \\
\hline Açık kitap & 29 & 33 & 32 & 26 \\
\hline Kapalı kitap & 15 & 13 & 17 & 11 \\
\hline $\begin{array}{r}\text { Açık-Kapalı kitap/ Hikâye karakteri yerine } \\
\text { geçmiş }\end{array}$ & - & - & 1 & 1 \\
\hline Toplam & 44 & 44 & 50 & 38 \\
\hline \multicolumn{5}{|l|}{ Kitap ve/ya Yazar İsimleri } \\
\hline Kitap ismi & 12 & 4 & 7 & 12 \\
\hline Yazar ismi & - & - & - & 2 \\
\hline \multicolumn{5}{|l|}{ Konuşma baloncukları } \\
\hline $\begin{array}{r}\text { Olumlu duygu ifadeleri ve/ya figürleri içeren } \\
\text { durum }\end{array}$ & 3 & 1 & & 6 \\
\hline Olumsuz duygu ifadeleri ve/ya figürleri içeren & - & - & - & 1 \\
\hline
\end{tabular}




\begin{tabular}{|c|c|c|c|c|}
\hline durum & & & & \\
\hline \multicolumn{5}{|l|}{ Düşünce baloncuklart } \\
\hline $\begin{array}{r}\text { Olumlu duygu ifadeleri ve/ya figürleri içeren } \\
\text { durum }\end{array}$ & 7 & 3 & 18 & 8 \\
\hline $\begin{array}{r}\text { Olumsuz duygu ifadeleri ve/ya figürleri içeren } \\
\text { durum }\end{array}$ & 1 & - & - & - \\
\hline
\end{tabular}

$\mathrm{Bu}$ tabloda yer alan bulgular, başlıklar altında öğrencilerin resimleri ve bu resimlere ilişkin değerlendirmelerle birlikte aşağıda açıklanmıştır.

\section{“Keyif-Neşe-Sevinç-Mutluluk-Ĕ̆lence” Duygu Durumlarının Çizimlerde Dă̆ılımına İlişkin Bulgular}

Okurken "mutlu" hissettiği belirlenen ilkokul öğrencilerinin ikinci ve dördüncü sınıftaki çizimlerine ait analiz sonuçlarına göre araştırmaya katılan öğrencilerin büyük bir bölümü hem ikinci sınıfta hem de dördüncü sınıfta okurken kendini mutlu/neşeli/sevinçli hissettiklerini ve okurken mutlu olduklarına dair duygu durumlarını her iki sınıf düzeyinde de en sıklıkla "ă̆gzdudak yukarı kıvrımlı" şekilde çizerek göstermiştir.
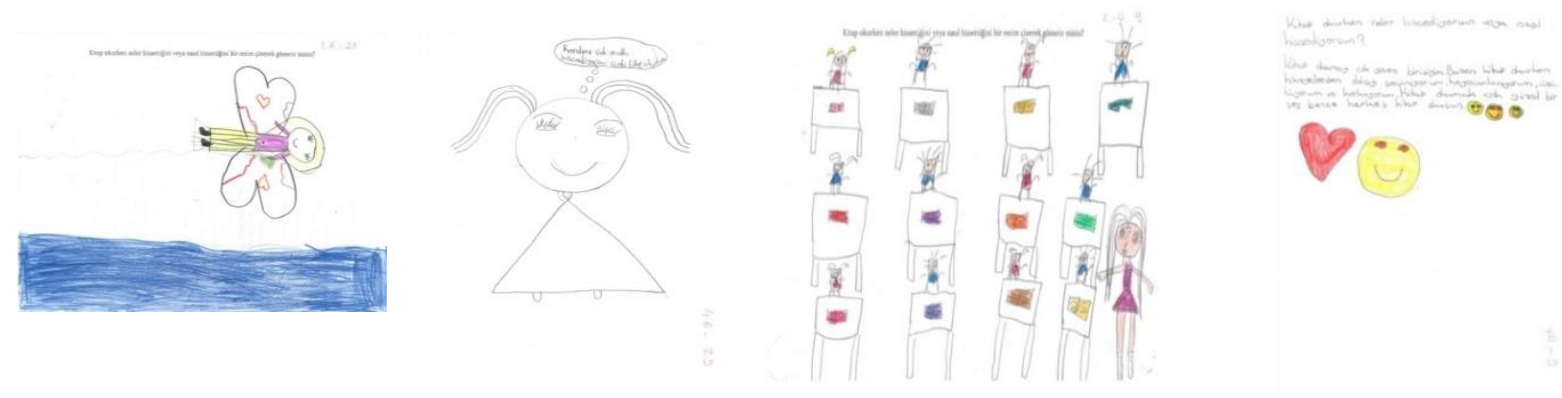

Resim 5. 2KK-21

Resim 6. 4GK-29

Resim 7. 2DK-9

Resim 8. 4DK-9

Sayıları diğer çocuklar kadar olmasa da araştırmaya katılan çocukların bir kısmının ise okurken "çok mutlu" olduklarını "dişleri görünecek ve dilleri dışa sarkacak" derecede ağızları açık şekilde çizdiklerini (2.sınıf Erkek: G-20; 4.sınıf Kız: C-15; D-11; G-6; M-7; 4.Sınıf Erkek: $C$-30) göstermektedir.

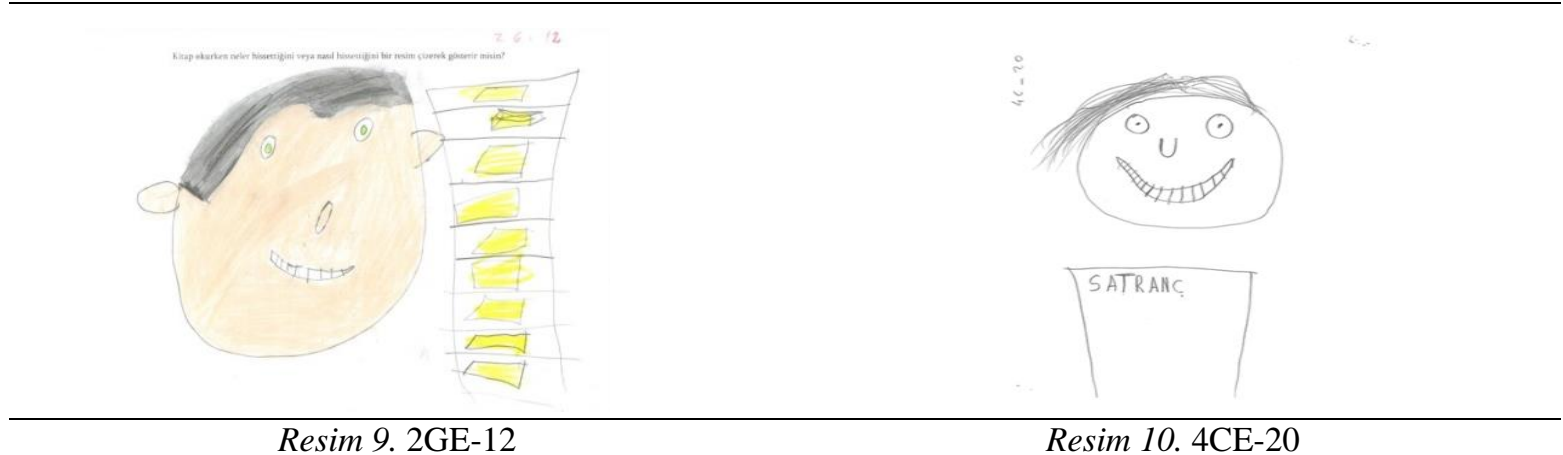

Aşağıdaki ilk resimde, kağıdın üst bölümünde oldukça büyük bir şekilde, saçları uzun, iki belik olan gözü, göz bebekleri, kirpikleri, burnu belirgin olan ve ă̆zı yukarı kıvrımlı olarak dili săga doğru çıkmış (4CK-15); ikinci resmin kurdeleli iki beliği, kirpikleri, yumuk gözleri belirgin olarak çizilmiş ve ă̆zı yukarıya doğru kıvrımlı dilini dışarı çıkarmış bir kız çocuğu görünmektedir (4MK-7). Üçüncü resimde, kâğıdın merkezinde gözleri, kaşları, burnu, ağzı ve dişleri belirgin, saçları şekilli, gözlüklü, oldukça büyük çizilmiş bir erkek çocuk baş- 
yüzü görünmektedir (4CE-30). Dişlerinin yan yana sıralı şekilde olmayıp aralıklı, dizildiği görünmektedir. Ayrıca ağzının arasından dile benzer uzunca bir biçim fark edilmektedir.

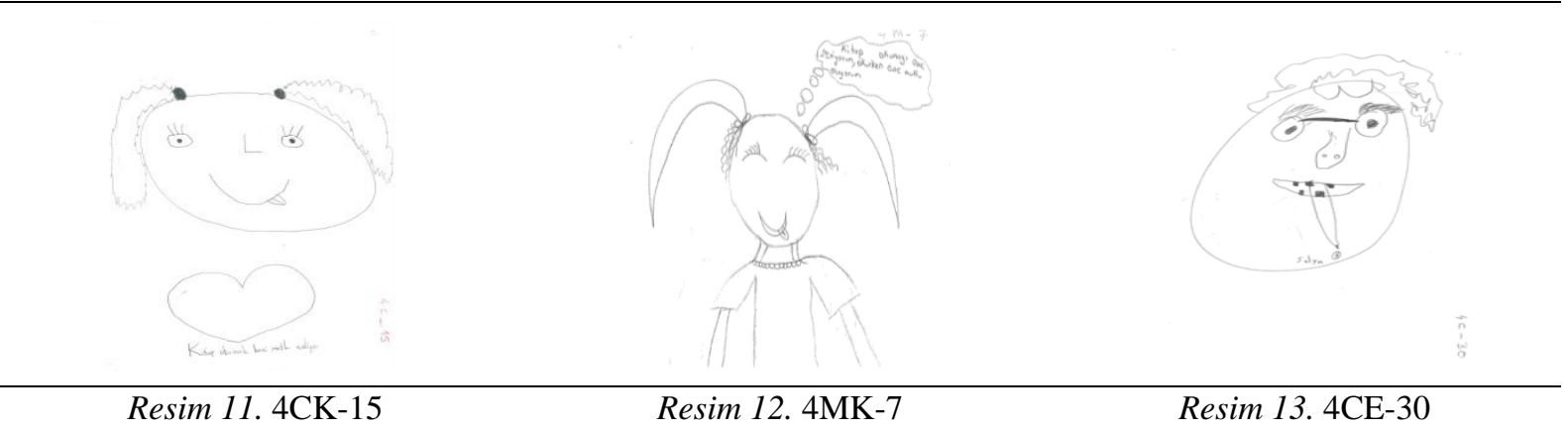

\section{"Şaşkın/lı, Heyecan/ll, Merak/l, Korku/lu, Kızgın, Öfke/li" Duygu Durumlarının} Çizimlerde Dağılımına İlişskin Bulgular

Aşağıdaki ilk resimde bir erkek çocuğu figürü yer almaktadır (4GE-5). Çocuğun saçları, kaşları, kulakları, gözleri, göz bebekleri, burnu ve açık ağzı belirgin olarak görünmektedir. Figürün başının hemen sağ tarafinda konuşma baloncuğu içinde "Çok şaşırdım acaba sonra ne olacak" ifadeleri yer almaktadır. Portreye bakıldığında, yuvarlak olarak ağzının açık ve gözlerinin hayret eder bir ifadenin olması, çok net olarak "şaşkınlı̆̆l" göstermektedir. Konuşma baloncuğunda yer alan "Çok şaşırdım acaba sonra ne olacak" ifadeleri de bu yüz ifadesini desteklemektedir. İkinci resimde (4GK-21), uzun sarı saçlı, gözleri, kirpikleri belirgin olarak ve ağzı da açık yuvarlak şekilde betimlenmiş bir kız çocuğu çizilmiştir. Başının üzerinde "üç soru "?" işareti” görünmektedir. Başının üstündeki "? ? ?" soru işareti, elinde tutmuş olduğu kitapta neler olduğunu merak ettiğine dair bir işaret olarak görülebilir. Çünkü soru işaretinin yanı sıra ăgzının yuvarlak bir şekilde "şaşkınlık" ifadesiyle gösterilmesinin bu duygu durumunu doğruladığı düşünülmektedir.

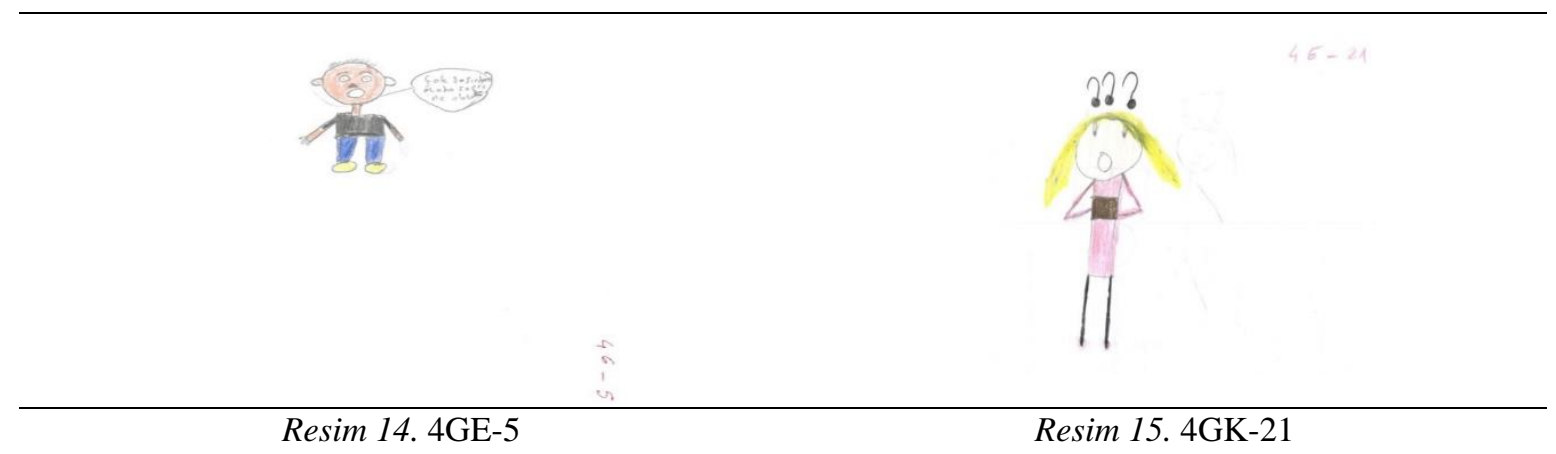

\section{Durgun Yüz-Yüzzün Eksik Olduğu (Nötr-Belirsiz-Net İfade Edilmeyen-Anlaşllamayan) Çizimlere İlişkin Bulgular}

Aşağıdaki ilk resimde, bir ev-okul çizilmek istenmiş ancak silinerek, güneş ve bulutun göründüğü, okul sıralarının dizildiği bir dış alan resmedilmiştir. (2DE-7). Çizimde okul sırasına benzer yan yana dizilmiş altı masa ve her bir masanın üzerinde biri yazılı olmak üzere altı adet açık kitap yer almaktadır. Bu altı sıranın üçünde kaşı, gözü olmayan insan figürlerinin oturduğu görünmekte ve figürlerin hiçbirinin duygu ifadeleri anlaşılamamaktadır. İkinci sıradaki resmin bütününe bakıldığında, (2KE-12), yeşil alanın resmin büyük bir bölümünü kapladığı söylenebilir. Sağ tarafta uzun gövdeli yuvarlak bir ağaç ve bu ağacın 
altında uzanmış iki figür varmış gibi görünmektedir. Ancak tek bir figürün de olabileceği düşünülmektedir. Çocuk çiziminin çok küçük olmasından dolay1, yüzdeki düz çizgi durgun bir ifade olarak anlaşılmaktadır. Burada duyguya dair ifadesinin net olmadı̆̆ söylenebilir.

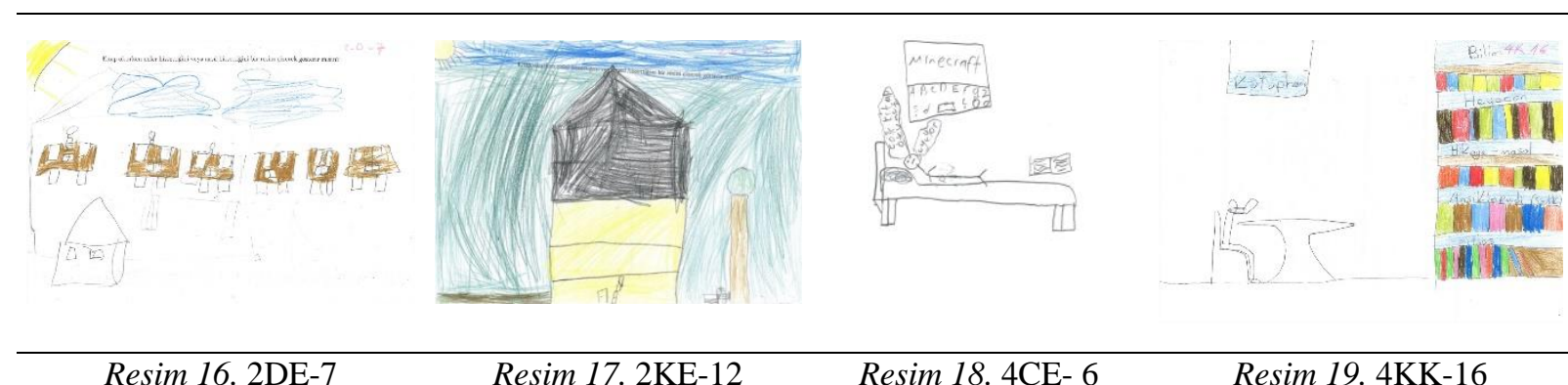

Yukarıda üçüncü sıradaki resmin bütününe bakıldığında kağıdın merkezine yakın orta büyüklükte, yatağa uzanmış bir erkek çocuğu görülmektedir (4CE-6). Bu çocuğun başının üstünde "Çok kitap okumuş" yazan bir düşünme baloncuğu ve başın yan tarafından "uyuyor" ifadesinin yazılı olduğu başka bir düşünme baloncuğu çıarılmıştır. Çocuğun gözleri kapalı, ăğ $\mathbf{z}$ düz bir çizgi şekilde uyuduğu görülmektedir.

Yukarıdaki dördüncü resmin sol üst bölümünde "Kütüphane" yazılı bir tabelayla desteklenen kitaplarla dolu bir kütüphane ortamı yansitılmaktadır (4KK-16). Sağ tarafta, kat kat bölümlenmiş kitap rafları bulunmaktadır. Her bir bölümün "Bilim", "Heyecan", "HikâyeMasal", "Ansiklopedi (Sözlük)" ve "Atlas" şeklinde adlandırıldığı ve her bir rafta yan yana rengârenk kitapların dizili olduğu görülmektedir. Sandalyede oturan ağzı, kaşı, gözü, saçı olmayan ancak elinde bir kitap olduğu düşünülen bir çocuk figürü yer almakta ve masada kitap okumaktadır. Ortamdaki göstergeler, resimdeki çocuğun kitap okumaktan keyif aldığını düşündürmektedir.

\section{Farklı Duygu Durumlarının İfade Edildiği Çizimlere İlişsin Bulgular}

İlkokul ikinci sınıftayken araştırmaya katılan öğrencilerden sadece altısının okurken "farklı duygular" hissettiği belirlenirken bu sayının öğrenciler dördüncü sınıfa geldiğinde iki katına çıktığı görülmektedir. Bu öğrencilerden sadece bir kız öğrencinin (2CK-8 / 4CK-8) hem ikinci hem de dördüncü sinıftayken okurken farklı duygular hissettiğini çizimlerine yansıttığı görülmüştür. Araştırma bulguları, öğrencilerin bu farklı duygu durumlarını farklı şekillerde ifade ettiklerini göstermektedir. Şöyle ki, bu farklı duygu durumlarını öğrencilerin bir bölümü sadece çizimlerle (Örneğin, 2LK-25; 2MK-16; 2GE-4; 4CK-28; 4KK-19; 4ME-30) veya sadece yazı ile (Örneğin, 2CK-8; 2CK-9; 4CK-8) yansitırken; bir bölümü ise hem çizim hem de yazı ile yansıtmıştır (Örneğin, 2KE-2; 4DK-15; 4LE-10; 4LK-22).

Farklı duygu durumlarının bir arada verildiği resimlerde "ağzı yukarı kıvrımlı ve/ya açık" şekilde gülümseyen, "dişleri görünecek şekilde" mutlu ve "ağzın düz çizgi" şeklinde nötr olarak çizildiği yüz ifadelerinin olduğu görülmektedir. Yine bu duygu durumlarının olduğu yazılı ifadelerde ise "üzgün bir olay, mutlu bir olay, bu kitap çok güzel çok komik, sıkıldım, anlamsız, sevdiğim-sevmediğim kitap, okumayı severim, okumayı sevmiyorum" şeklinde doğrudan öğrencilerin okurken hissettikleri ve okuduğu kitaplara dair hissettikleri yazılı duygu ifadeleri yer almaktadır. 


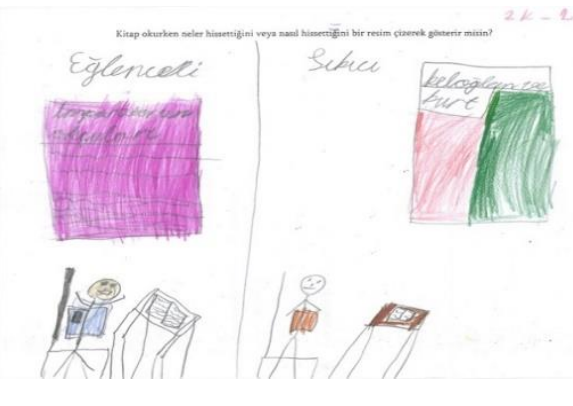

Resim 20. 2KE-2

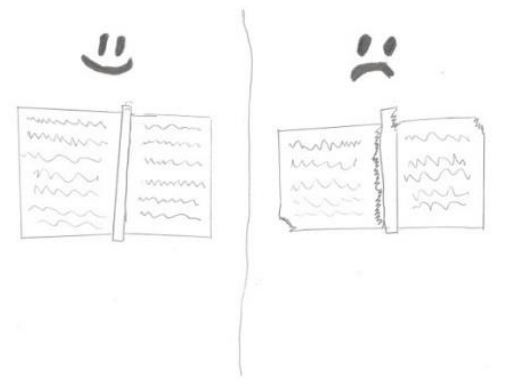

Resim 21. 4DK-15

İkinci sınıf öğrencilerinden biri (2KE-2), resminde iki faklı bölümdeki masalarda açık yazılı kitapları okuduğunu göstermekte ve okuduğu kitapları örnek vermektedir. Öğrenci burada okurken farklı duygular hissettiğini resimde sınıflandırarak yansıtmak istemiştir. $\mathrm{Bu}$ sınıflandırmayı hem figürlerin yüz ifadeleriyle hem de yazılı olarak gerçekleştirmiştir. Farklı duyguları hissetmesine neden olan eser isimlerini de belirtmiş olduğu görünmektedir. $\mathrm{Bu}$ duyguları, "eğlenceli" olarak adlandırılan bölümde ăgzı açık bir çocuk figürüyle; "sıkıcı" olarak adlandırılan bölümde ise dudağı düz çizgi şeklinde olan bir çocuk figürüyle ifade etmiş̧ir.

Dördüncü sınıf öğrencilerinden birinin (4DK-15) resminde ortadan dikey çizgiyle ikiye ayrıldığı ve her bir bölümüne büyük ölçüde açık yazılı birer kitap çizildiği görülmektedir. Bu iki kitabın her birinin üst bölümünde belirgin olarak, büyük ölçüde, emoji karakterinde ăgzl yukarı kıvrıml gülümseyen bir yüz ve ağzı aşă̆ı doğru kivrımlı asık bir yüz görünmektedir. Resimde, bir okuma eylemi yansıtılmamış olmasına karşın, araştırma sorusuna doğrudan yanıt vermeye yönelik bir çizim örneği olduğu düşünülmektedir. Öğrenci, okurken hissettiği duygulardaki farklılıkları, iki kitabın figürlerinin yüz ifadelerindeki ayrımlarını gösterecek düzeyde yansıtma çabası gütmüştür. Kitapların her birinin üst bölümünde öğrencinin okurken hem mutlu hem de üzgün hissettiği zamanların olduğunu gösteren "emoji” yüz ifadeleri, aynı zamanda kitapları iyi ve kötü kullanma davranışına da işaret etmektedir.

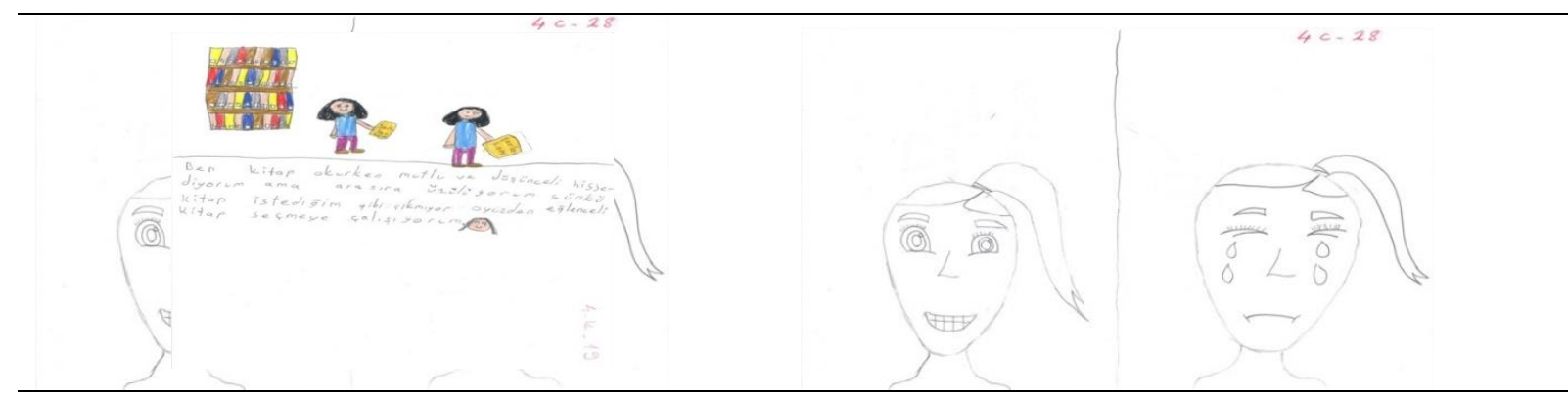

Resim 22. 4KK-19

Resim 23. 4CK-28

Okurken farklı duygular hissettiği düşünülen resimlerden birinde öğrenci (4KK-19), sol tarafta dört kat rafta sıralı ve tamamıyla dolu, renkli, etiketli kitapların olduğu bir kitaplık resmetmiştir. Raflarda sıralanmış kitapların belirgin, düzenli ve farklı renklerde olması kitabın önemini ve çeşitliliğini vurgulamaktadır. Bu kitaplığın yakınında birbirinin aynısı olan iki kız çocuğu figürü yer almaktadır. Ancak kız çocuklarının yüz ifadeleri duygu yönünden farklılık göstermektedir. Kitaplığa yakın olan kız çocuğu dişleri görünecek şekilde ağzı yukarıya doğru açılmış ve elinde "Şarlakom (Sherlock Holmes)" yazan sarı kapaklı bir kitap ile 
görünmektedir. Diğer taraftan kitaplığa uzak olan kız çocuğunun yüzü yine aynı eseri elinde tuttuğu ancak düz bir ăglz ifadesiyle (kaş durumuna da bakılarak) hüzünlü olduğu görünmektedir. Duygularındaki bu farklılığı hem netleştirmek hem de hangi nedenlerle bu duygularını hissettiğini açıklamak için de "Ben kitap okurken mutlu ve düşünceli hissediyorum ama ara sıra üzülüyorum çünkü kitap istediğim gibi çıkmıyor oyuzden eğlenceli kitap seçmeye çalışıyorum." şeklinde yazılı ifadelere gereksinim duyduğu anlaşılmaktadır. Aynı eseri okurken mutlu-hüzünlü farklı duygular hissettiğini yansitmakla birlikte genel olarak okumaktan ne kadar keyif aldığını ve mutlu olduğunu açıklamalarının sonundaki gülen yüz ifadesiyle de göstermektedir.

Resmin tam ortasında (4CK-28), dikey bir çizgi çekilerek çizginin her iki yanına duygu durumları dışında birebir aynı olan birer kız çocuğu portresi resmedilmiştir. Çizimdeki portrelerin betimlemelerine bakıldığında, saç biçimleri ve saçlarının ayrılma noktaları iki portrenin de aynı kişiye ait olduğunu göstermektedir. Sol bölümdeki portrenin göz bebeklerine kadar belirgin olarak çizilmesi dikkat çekmektedir. A $\breve{g} ı z$ çok açık ve dişler bütünüyle görünmekte ve dişlerini özellikle gösterircesine gülümsediği fark edilmektedir. Sağ bölümdeki portrede ise hem yumuk olan gözlerinden akan gözyaşlarından hem de aşağıya doğru kıvrılmış ă̆ız ifadesinden mutsuz olduğu açıkça görülmektedir. Resimde öğrencinin kendisini resmettiği düşünülmektedir. Bu tespitler, öğrencinin kitap içeriğine göre okurken farklı duygular hissettiğini belirgin olarak göstermektedir.

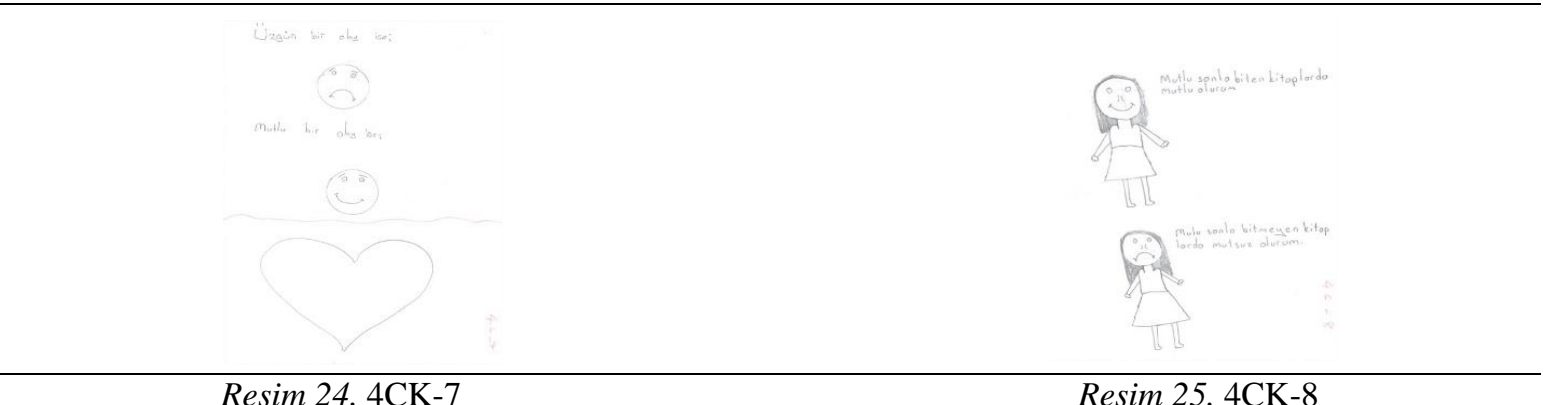

Resim 24. 4CK-7

Resim 25. 4CK-8

Yukarıda yer alan kız çocuğu portreleriyle (4CK-28); benzer şekilde üstteki her iki resimde de (4CK-7; 4CK-8) ne okumaya ne de kitaba dair herhangi bir biçim bulunmamaktadır. Bununla birlikte resimlerdeki emoji yüz karakterleri ve kız çocuklarının yüz ifadeleri, okurken nasıl hissettiklerini göstermektedir. Ağılarının aşağıya kıvrımlı açık olması onların mutsuz olduklarının; yukarıya kıvrımlı olması ise mutlu olduklarının açık bir göstergesidir. Ancak neden farklı duygular hissettiklerini de yazılı olarak belirterek; kendilerini iki ifade aracıyla daha net yansıtmaya gereksinim duymuşlardır. Bunlara dayanarak öğrencilerin duygularını ifade etmede paylaşıma açık oldukları ve okur-yazarlıkları konusunda da bilgilerini göstermeye yöneldikleri söylenebilir. Bu şekilde farklı duyguların bir arada ifade edildiği çizimler bu durumların bize, bir taraftan çocukların farklı duyguları yaşatan eserler okuduklarını gösterebileceği gibi diğer taraftan öğrencilerin çizimlerdeki yüz ifadelerinin yanı sıra yazılarıyla da desteklediği gibi eserlerin sıkıcı olmasından da kaynaklanabileceğini düşündürmektedir. 


\section{Duygu Durumlarının “Kalp” Figürleriyle İfade Edildiği Çizimlere İlişkin Bulgular}

Öğrencilerin okurken hissettiklerine yönelik duygu durumlarının doğrudan ifade edildiği figürlerden biri olarak da çizimlerde farklı büyüklükte ve sayıda olmak üzere kalp figürlerine yer verilmiştir. $\mathrm{Bu}$ figürleri, sayısal olarak hem ikinci sınıftayken $(\mathrm{k} / \mathrm{f}=28$; e/f=11) hem de dördüncü sınıftayken $(\mathrm{k} / \mathrm{f}=20 ; \mathrm{e} / \mathrm{f}=6) \mathrm{k}$ ız öğrencilerin erkek öğrencilere göre daha çok tercih ettiği dikkat çekmektedir. Ayrıca kalp figürlerini araştırmaya katılan bazı öğrencilerin sadece bir tane "büyük" veya "küçük" olarak çizdikleri bazı öğrencilerin ise birden fazla "büyük" veya "küçük" olarak çizdikleri belirlenmiştir.

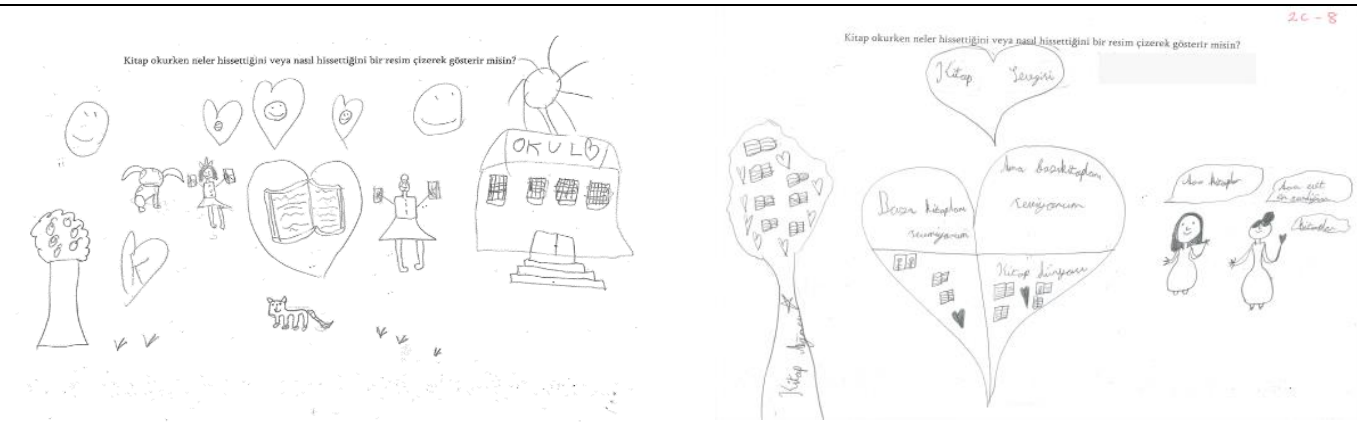

Resmin bütününe bakıldığında, (2CK-5), çizimde ellerinde ikişer kitap olan iki insan figürü, bir kedi ve bir köpek, meyveli bir ağaç, emoji karakterinde iki baş, 1şık saçan bir güneş ve içinde gülen yüz olan üç kalp ile kitap kelimesinin ilk harfi "K" olan bir başka kalp yer almaktadır. Ayrıca çizimde parmaklıklı dört penceresi olan merdivenli bir bina görünmektedir. Çatısına “Okul” yazılmış ve bir küçük kalp çizilmiştir. Resimdeki figürlerden birinin öğrenci, topuz saçlı olan kişinin ise öğretmen olduğu anlaşılmaktadır. Resmin tam merkezinde diğer kalplerden daha büyük bir "kalp" bulunmaktadır. Bu kalbin içine büyük bir kitap çizilmiştir. Bu, sayfaları çok olan, kalınca ve satırları gösterilmiş bir kitaptır. Okulun yakınındaki bu "kalp" çizimi, çocuğun okulunu sevdiğini ve okulu dişarıdaki tehditlerden koruyan, sığınak, güvenli bir yer olarak algıladığını düşündürmektedir. Okulun çatısındaki kalp bu düşünceyi destekler durumdadır. Çocuğun ve öğretmenin yüzlerinin gülmesi, ortak şekilde hareket etmeleri resimdeki çocuğun öğretmeniyle iyi iletişim kurduğunu ve kitap okumaya yönlendirmesi konusunda olumlu bir etki oluşturduğunu düşündürmektedir. Burada kitap okumanın önemini okul ile ilişkilendirerek yansıtmak istediği düşünülebilir. Kalpler ve içindeki gülen yüzlerle birlikte resmin merkezindeki büyük kalp içinde ayrıntılarıyla bir kitabın resmedilmesi, resmi çizen öğrencinin okurken ne kadar olumlu duygular hissettiğini göstermektedir.

Resimde, birinin elinde yıldız, diğerinin elinde kalpli değnek bulunan iki insan figürü yer almaktadır (2CK-8). İkisinin de ağızları yukarı kıvrımlı şekilde mutlu görünmektedir. Resmin merkezinde, büyükçe bir kalp çizilmiş ve dört bölüme ayrılmıştır. Üstteki iki bölüme "Bazı kitapları sevmiyorum.", “Ama bazı kitapları seviyorum.” ifadeleri yer almaktadır. Alt bölümde, iki tarafta da ikisi resimli; dördü de yazılı kitap olmak üzere yedi kitap çizilmiştir. Resmin üst bölümünde, orta büyüklükteki kalbin içinde "Kitap Sevgisi” ifadeleri yazılıdır. Büyük kalbin alt bölümünde ise "Kitap Dünyası" ifadeleri yer almaktadır. Yani bu ifadeler öğrencinin, kitabın zengin, çeşitlilik arz eden, çok büyük bir dünya olduğunu düşündüğünü göstermektedir. 'Kitap Dünyası'nda resimli kitap çizmesi bu tür kitaplara olan ilgisinin de 
devam ettiğini göstermektedir. Resmin sol tarafında, çizdiği ağacın adına "Kitap Ağacı" adını vererek yıldız “*” sembolü ile kitapların bizi aydınlattığını anlatmaya çalışmış olduğu söylenebilir. Ayrıca bu ağaçta her biri ağacın meyveleri olarak düşünülebilecek yedi açık kitap resmedilmiştir. Öğrenci kalpleri de ağacın yaprakları gibi düşünerek kitaplara olan sevgisini bir kitap ağacında gösterip kitapların verimliliğine işaret etmek istemiş olduğunu düşündürmektedir.

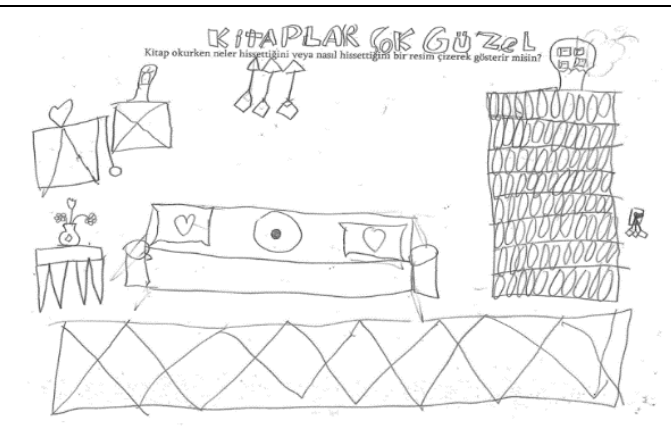

Resim 28. 2CK-12

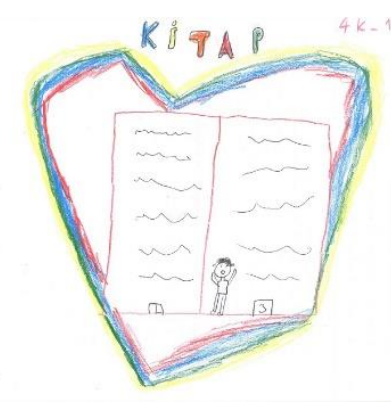

Resim 29. 4KE-11

Resmin bütününe bakıldığında (2CK-12), bir evin salonunun eşyalarıyla ayrıntılı olarak çizildiği görünmekte; hiç insan figürünün ve okuma eyleminin olmadığ dikkat çekmektedir İç mekânda, uzun bir kanepe ve kanepede ikisi kalpli biri yuvarlak üç yastık, sehpa ve üzerindeki vazoda üç çiçek, yerde desenli bir halı ve tavanda avize görünmektedir. Ayrıca (üçlü), biri kalp ile süslenmiş iki pencere bulunmaktadır. Bunların yanı sıra tamamı kitaplarla dolu olan sekiz raflı bir kitaplık yer almaktadır. Resmin en üst bölümünde büyük harflerle "KİTAPLAR ÇOK GÜZEL" ifadeleri yazılmıştır. Bu yazının resmin üst bölümünü ortalayarak büyük, kalın ve süslü bir şekilde yazmak için özen gösterildiği anlaşılmaktadır. Odanın içinde hiç insan figürünün olmaması, resmi çizen öğrencinin kitaplı̆̆g olan bir ev hayal ettiğini gösterebilir. Ancak bir öğrencinin ikinci sınıf düzeyinde, perde çekeceğini, avize, fiş yeri ya da aplik ve diğer elemanları ayrıntılı çizmesi, bir gözleminin olduğuna ve eşyalar üzerinde kalplerin olması hoşnut olduğu bir alanı çizdiğine de işaret etmektedir. $\mathrm{Bu}$ bağlamda her iki görüşte de öğrencinin salondaki kitaplık ve ortamın düzenli, hoş, güven hissettiren ev hali görünümüyle okuma sevgisini doğrudan vermek istediğini düşündürmektedir. Öğrenci, kitaplara karşı sevdiğim-sevmediğim şeklinde duygularını ayrıntılı ifade etmese de onun kitapları çok güzel bulması genel olarak kitaplar hakkındaki olumlu hislerini doğrudan ortaya koymaktadır.

Resim 29'da, kâğıdın merkezinden bütüne doğru büyük bir boyutta sarı-yeşil-mavi ve kırmızı renkli olmak üzere iç içe geçmiş bir "kalp" biçimi görünmektedir (4KE-11). Bu kalbin ortasında büyük boyutta kırmızı renkte, sayfaları yazılı açık bir kitap çizilmiş ve kitabın alt sınırında "2" ve "3" olmak üzere sayfa numaraları yazılmıştır. Kitabın sayfalarını yazması hakkını vererek gerçekçi biçimde yansıtma ve özenli çizme isteğini göstermektedir. Burada özenli çizimden kasıt, öğrencinin çabalama isteğine vurgu yapmak ve öğrencinin kitaba verdiği önemi ifade etmektir. 


\section{Duygu Durumlarının “Kitap” Figürleriyle İfade Edildiği Çizimlere İlişkin Bulgular}

Öğrencilerin okurken hissettiklerine yönelik duygu durumlarının doğrudan ifade edildiği figürlerden bir diğeri farklı şekillerde tasarlanmış "kitap" figürleridir. Araştırmaya katılan hem kız hem de erkek öğrencilerin yaklaşık olarak yarısının hem ikinci sınıfta $(k ı z(f)=29$ / erkek $(f)=33)$ hem de dördüncü sinıfta $(k 1 z(f)=32 /$ erkek $(f)=26)$ resimlerinde, okurken hissettiklerine yönelik duygu durumlarını ifade ederken açık kitap figürlerini çizdikleri belirlenmiştir. $\mathrm{Bu}$ figürlerde kimi kitabı okuyorken, kimi okuyacakken, kimi ise açık kitap elinde, önünde, yanında veya yakınında olarak resmedilmiştir. Benzer şekilde yine hem ikinci hem de dördüncü sınıfta öğrenciler, birbirine yakın oranlarda okurken hissettiklerini ifade etmek için kapalı kitap figürleri çizmişlerdir. Bu figürlerde de çocuklar kapalı kitabı elinde, önünde, yanında ve/ya yakınında olacak şekilde konumlandırmışlardır. Ayrıca dördüncü sınıf öğrencilerinden sadece ikisi ise "hikâye karakteri yerine geçmiş" olarak açık ve/ya kapalı kitap figürleri çizerek duygu durumlarını ifade etmiştir. Bu öğrencilerden ilki (4KK-6) "Kitap okurken kendimi orda hissediyorum" ifadelerini yazarak yüzü gülümseyen bir "emoji” çizerken ikincisi ise (4KE-5) "O an okuduğum bilim kitabının içindeki ana karakterin yerindeyim" şeklinde duygularını yazıyla ifade etmiştir.

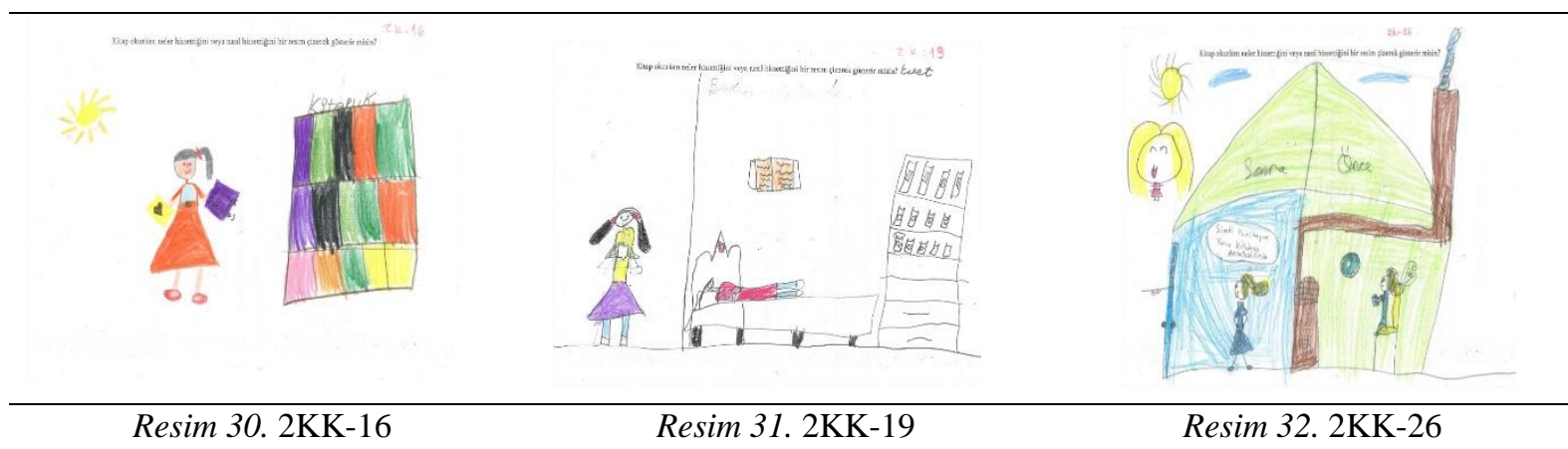

Yukarıdaki ilk resimde (2KK-16), sol bölümde üzerinde "KİTAPLIK" yazan üç katlı, raflı bir kitaplık görülmektedir. Her bir rafta rengârenk boyanmış beşer kitap bulunmaktadır. Resmin merkezinde, bir kız çocuğu figürü bulunmaktadır. Figürün yüzü ağzı yukarı kıvrımlı olarak gülümsemektedir. İki elinde de biri üzerinde kalp olan diğer elinde de "Pamuk Prenses" yazan iki kitap görülmektedir. Kitapların renkli olması, güneşin bütün ve parıldıyor olması, çocuk figürünün gülümsemesi ve özenli görünmesi, kitapların renkli ve belirgin olarak resmedilmesi, kitap kapaklarının boyanarak ve ismiyle belirtilmiş olması, kalp çizilmesi resmin bütününde öğrencinin kitap okurken mutlu olduğunu göstermektedir.

Yukarıdaki ikinci resmin bütününe bakıldığında, araştırma sorusuna "Evet" şeklinde yazılı yanıt verildiği görülmektedir (2KK-19). Resim dikey çizgiyle ikiye bölünmüş ve sol tarafında yer çizgisinin üzerinde göğüs hizasında bir kitap olan yüzü mutlu bir kız çocuğu çizilmiştir. Resmin sağ bölümü daha geniş bir alanı kapsamakta ve yer çizgisi devam etmektedir. Raflarında kitapların olduğu bir kitaplık ve yanında süslü yatak başının olduğu uzun bir yatak yer almaktadır. Solda dikey duran mutlu kız çocuğunun, yatağın üzerinde göğsünde kitapla yatağa uzanmış hali görünmektedir. Ayrıca yatağın üst bölümünde, açılmış yazılı bir kitap görülmektedir. Bunlara dayanarak her iki bölümde de kitap okuma eyleminin etkin olarak gerçekleştiği ve çocuğun kitaplarla mutlu olduğu anlaşılmaktadır. Öğrencinin odasında konforlu ortamında yatarken kitap okumaktan hoşlandığı söylenebilir. 
Resim 32'de, solda güneş 1şımakta ve gökyüzünde iki mavi bulut yer almaktadır (2KK-26). Tam merkezde, çatısından aşağı doğru çizgiyle ikiye bölünmüş büyük bir ev görülmektedir. Evin çatısında sol tarafına "Sonra", sağ tarafına "Önce" kelimeleri yazılmıştır. Ev saydam olarak resmedilmiştir. Ayrıca sağ tarafta, odanın içinde süslü sandalye üzerinde açık kitap okumakta olan uzun saçlı, bir kız figürü bulunmaktadır. "Sonra" kelimesinin yazılı olduğu bölümde, sağ taraftaki karakterin aynısı olan: uzun saçlı, ağzı aralık yüzünün güldüğü belli olan ve başı kapıya yönelmiş bir kız figürü durmaktadır. Düşünme balonunda "Şimdi harikayım. Yarın kitabımı anlatabilirim.” ifadeleri yazmaktadır. Evin dışında, güneşin altında ağzı açık olarak gülen, başı büyük ayrıca bir kız figürü çizilmiştir. Kapının, ışıklığın, saatin, sandalyenin, figürlerin, kitabın son derece ayrıntılı, incelikle çizilmiş olduğu resimde bir kitabın olduğu ve okuma eyleminin gerçekleştirildiği görülmektedir. Diğer kız figürleriyle birlikte, dışarıdaki kızın gözlerinin yumulurcasına kısılmış olarak ağzının açık mutlu yansıtılması öğrencinin kendini çok iyi hissettiğini göstermektedir.

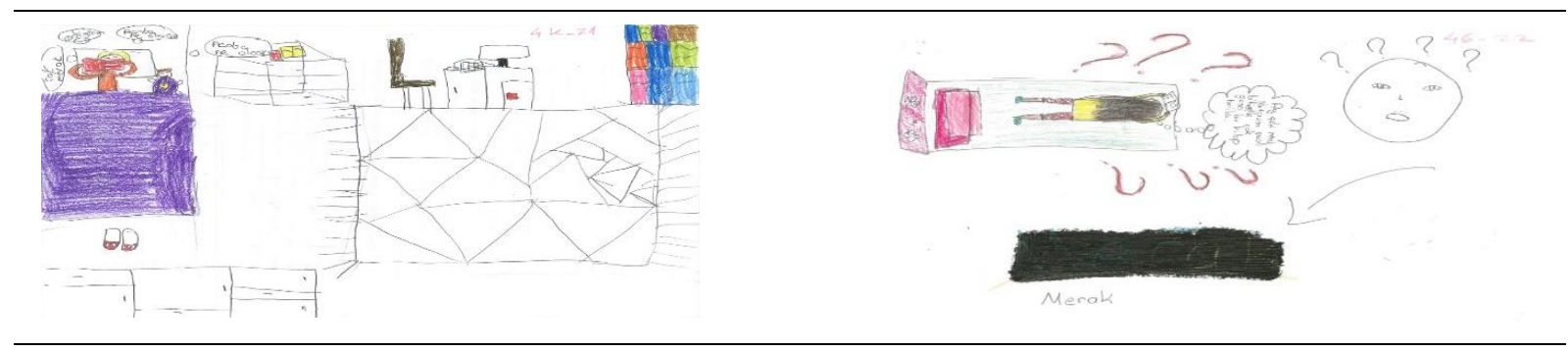

Resim 33. 4KK-21

Resim 34. 4GK-22

Yukarıdaki ilk resmin (4KK-21), özenli ve ayrıntılı yapıldığı öncelikle dikkat çekmektedir. Resmin solunda bir yatak içinde sırt üstü uzanmış, elinde açık bir kitap tutan, sarı saçlı bir kız çocuğu görülmektedir. Çocuk okuma eylemindedir ve sadece kaşları görünmektedir. Kız çocuğu başını yastığa koymuştur. Yastığın çevresinde "çok merak", "ediyorum”, “Acaba ne olacak” yazılı üç ayrı düşünce baloncuğunun olduğu görünmektedir. Yatağın yanında çekmeceli küçük bir dolap ve üzerinde biri açık ve yazılı, bir diğeri kapalı olmak üzere renkli iki kitap resmedilmiştir. Bu kitapların üstünde düşünme baloncuğu içinde "Acaba ne olacak" cümlesi yazılmıştır. Bir masa üzerine bilgisayar ekranı, klavye, fare yerleştirilmiştir. Masanın önünde bir koltuk ve yanında üç rafta rengârenk sıralanmış kitaplar yer almaktadır. Bu yönleriyle resmin bütününe bakıldığında, çeşit çeşit kitaplar ve kitap okuma eylemi görülmekle birlikte; okuma eylemi esnasındaki duygu durumunu gösteren yüz ifadesi çocuğun yüzü kitabın arkasında kalması nedeniyle görülmemektedir. Diğer taraftan odanın tamamı incelendiğinde öğrencinin odasının duygu durumunu ortaya koymasını sağlayan bir ortam oluşturduğu ve bunu özellikle göstermeye çalıştığı söylenebilir. Ayrıca düşünme baloncuklarının içinde yer alan cümleler öğrencinin okuduğu kitaplarda heyecanlandığını göstermektedir.

Resim 34'te, (4GK-22), sol üst bölümde yatakta yüzükoyun bir şekilde uzanarak, elinde açık yazılı kitap tutmuş bir kız çocuğu görülmektedir. Bu çocuğun başının yukarısında "Ay çok merak ediyorum nasıl bitecek çok güzel bir kitap harika." cümlesinin yazılı olduğu düşünme baloncuğu dikkat çekmektedir. Yatağın üst bölümünde üç, alt bölümünde üç olmak üzere altı soru işareti "? ”yer almaktadır. Resmin sağ üst bölümünde gözleri ve göz bebekleri, burnu, ağzı olan bir yüz ve bu yüzün üstünde sıralı bir şekilde dört soru işareti "? ? ?" görülmektedir. Yüzün aşağısında sol tarafa doğru uzanan bir “ok işareti” görülmekte ve bu ok 
"siyah bir lekeyi" işaret etmektedir. Bu siyah lekenin alt katmanında "boyama-kazıma tekniği" ile yapılmış "Merak" kelimesi yer almaktadır. Yazılı siyah boyanın aşağısına kara kalemle "Merak" kelimesi orta büyüklükte yinelenmiştir. Çocuğun yüz üstü uzanıyor olması nedeniyle yüz ifadesinin nasıl olduğu anlaşılamamaktadır. Ancak kendi yaşam alanında, kelebekli yatağının üzerinde, yüzükoyun bir şekilde, sevdiği kitap türünü düşünerek kitabını okuduğu görülmektedir. Bu yönleriyle çocuğun kitap okurken kimi zaman şaşırdığı, kimi zaman eğlendiği kimi zaman da merak ettiği kısacası farklı duygular hissettiği sonucuna varılabilir.

\section{Duygu Durumlarının “Düşünme Baloncuğu” Figürleriyle İfade Edildiği Çizimlere İlişkin Bulgular}

Araştırmaya katılan öğrencilerin okurken hissettiklerine yönelik duygu durumlarının doğrudan ifade edildiği figürlerden biri “düşünme baloncuklarl”dır. Öğrencilerin resimlerde düşünme baloncuğu figürlerine yer vermeleri bakımından sınıf düzeylerine göre farklılık olduğu belirlenmiştir. Şöyle ki ikinci sınıftayken düşünce baloncuğuna yer veren öğrenci sayıs 10 iken dördüncü sınıftayken ise bu sayının yaklaşık olarak üç katı arttığ1 ve sayının 27 olduğu belirlenmiştir. Araştırmaya katılan öğrencilerden sadece birinin (2CK-9) düşünme baloncuklarıyla okumayı hem sevdiği hem de sevmediği durumlar olduğunu ifade etmiştir.

Düşünme baloncukları incelendiğinde, ikinci sınıf öğrencilerinin bu baloncuklarda okuma sevgisi (2CK-9; 2MK-17), özgürlüğün simgesi olarak kitap (2GK-22), okurun hayal dünyasını (2LK-12; ME-15) yansıtan figür ve açıklamalarının olduğu belirlenmiştir. Bunların yanı sıra araştırma sorusu ile ilişkisi kurulamayan "Kilosu 3 lira (2CE-20)" ve "Kitap 100 / A 100 (2GE-11)" şeklinde ifadeler de bulunmaktadır.

Bu baloncuklarda ağırlıklı olarak öğrencilerin okurken "mutlu” hissettiğini "ha ha ha, ...çok güzel”, “...çok seviyorum”, “...çok mutlu hissediyorum”, “...çok merak ediyorum”, "...çok güzel” şeklinde ifade ettiği, eserle bütünleştiğini gösteren "kitabın içinde hissediyorum”, “...ne güzel dalmışım sanki oradayım”, “...hayallere dalarım” şeklinde ifade ettiği, bunların yanı sıra “...okumak çok güzel” ifadeleriyle de okuma eylemine yönelik iyi duygular hissettiği belirtmiştir. Öğrencilerden biri ise okurken farklı duygular hissettiğini “emoji”ler aracılığıyla göstermiştir.

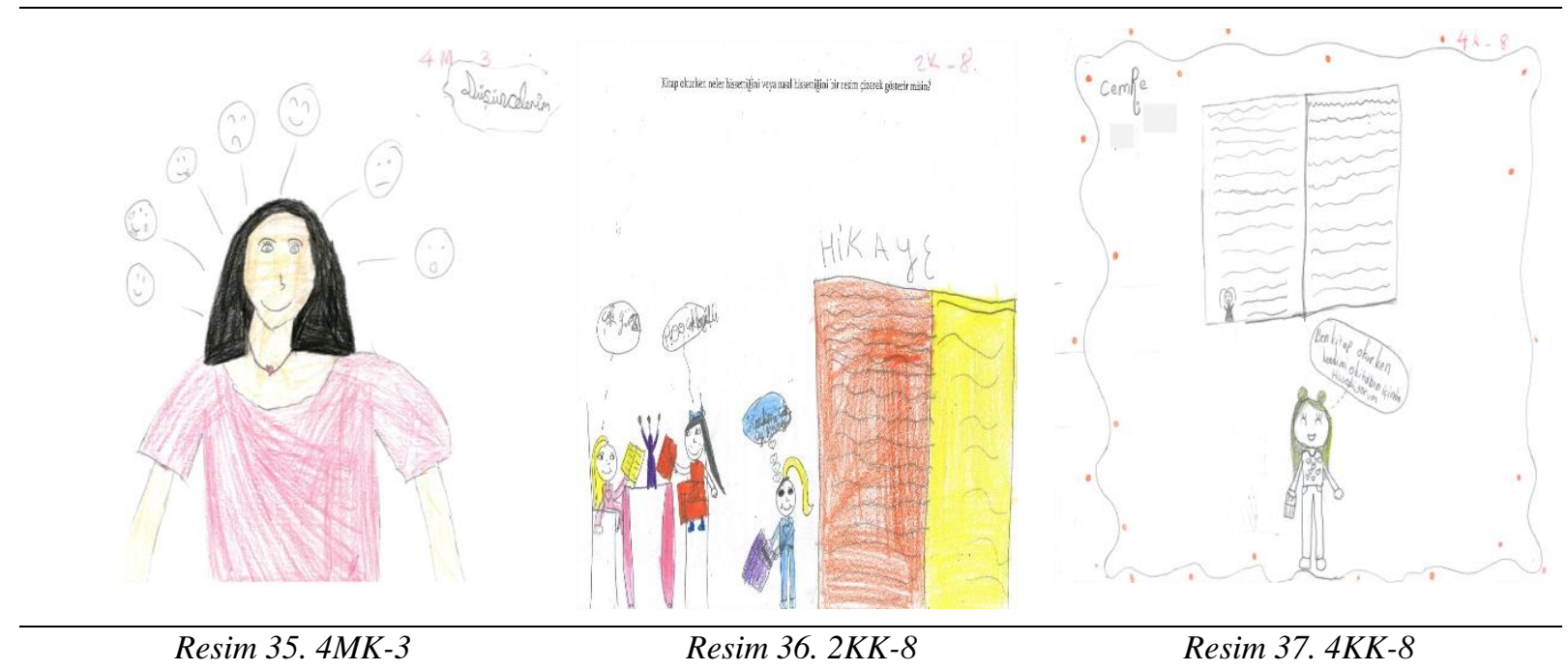


Resmin merkezini kaplayan bir kız çocuğu portresi görülmektedir (4MK-3). Başının üzerinde soldan başlayarak hilal şeklinde dizilmiş yedi emoji sembolü yer almaktadır. $\mathrm{Bu}$ semboller soldan sağa gülen, ağlayan, dili dışarıda, öfkeli, mutlu, donuk imge gibi nötr ve şaşkın olmak üzere farklı duygu durumlarını ifade etmektedir. Ayrıca sağ üst köşede "Düşüncelerim" yazılı bir düşünme baloncuğu görünmektedir. Bu çizimde, çocuğun kitap okuma esnasındaki her bir duygu durumunu bir emoji sembolü ile vermek istediği anlaşılmaktadır. Yüz ifadeleri yalın ancak farklı duygu durumlarını yansıtacak çeşitlilikte sıralanmıştır. Ayrıca resmin sağ tarafında yer alan düşünme baloncuğundaki "Düşüncelerim" ifadesi ve kolyesindeki kalp de bu duygu durumlarını desteklemektedir.

Resim 36'da, sağda “HİKAYE” yazısının aşağısında renkli, açık ve yazılı, büyük bir kitap, sol tarafinda ise üç figür görünmektedir (2KK-8). Bu figürlerden ilki ayakta durmakta ve elinde yazılı, resimli açık bir kitap tutmaktadır. Gülümsediği görülen bu kız çocuğunun başının üstünde kalp şekilleri düşünce baloncuğunu işaret etmekte ve bu baloncukta "Kendimi çok iyi hissediyorum" ifadesi yer almaktadır. Ayrıca bir masanın etrafında, karşılıklı oturan ve birbirlerine benzemeyen iki çocuk figürü bulunmaktadır. Bu çocukların ellerinde birisi resimli olmak üzere birer açık kitap bulunmakta ve ağızlarının yukarı kıvrımlı bir şekilde gülümsemesi belirgin olarak görülmektedir. Bu çocuklardan birinin üstünde bir baloncukta "çok güzel”; diğerinde ise "Ho çok keyifli" ifadeleri yazılıdır. Masanın üstündeki vazoda çiçeklerin yer alması çok güzel bir atmosfer içinde olduklarını göstermektedir. Çocukların renkli kıyafetlerinin üzerindeki kalplerden sevgi dolu oldukları; yüzlerinin gülmesinden de hallerinden çok memnun oldukları ifade edilebilir. Tüm baloncuklarda kitap okurken nasıl hissettiklerine yönelik destekleyici açıklamalar söz konusudur. Farklı karakterde çizilmiş çocukların okuma anlarından mutlu olduğu ve öğrencinin arkadaşlarıyla ya da sevdikleriyle birlikte okurken aynı mutluluğu duyumsadığını göstermek istediği söylenebilir. Tüm bu yazılı ve görsel unsurlar, öğrencinin okurken nasıl hissettiğini vurgulamaya yönelik çabasını ve paylaşma isteğini göstermektedir.

Resim 37'de, kağıdın dış çizgisinden içeriye doğru dalgalı bir çizgi karakteriyle bir çerçeve (Sanki süslü bir kitap sayfası gibi) ve çerçevenin içine ve dışına kırmızı noktalar yapıldığı görülmektedir (4KK-8). Bu çerçevenin merkezine orta büyüklükte satırları olan açık bir kitap ve kitabın sol sayfasının alt köşesine, küçük ölçüde bir kız çocuğu çizilmiştir. Kitabın aşağısında ayrıca büyük ölçüde belirgin olarak bir kız çocuğu resmedilmiştir. Kız çocuğu satırları olan açık bir kitap tutmaktadır. Elindeki kitap titizlikle çizilmiş ve bluzunun üstündeki kalpler, pantolonundaki cepler ve saç biçimine yönelik ayrıntılar yansıtılmıştır. Başının sağ tarafında düşünce baloncuğunun içinde "Ben kitap okurken kendimi o kitabın içinde Hissediyorum” cümlesi yer almaktadır. Resimdeki ayrıntıları gösterme gayreti, çizen öğrencinin duygu ve düşüncelerini atlamadan, eksiksiz olarak ifade etmek istediğini düşündürmektedir. Kağıdın sol köşesinde "CemRe A.... 4/K" yazısı bulunmaktadır. Cemre'nin "R" harfinin son kısmını aşağıya doğru uzatıp kıvırarak üstüne "iki nokta .." şeklinde gülümseyen bir yüz ifadesi yapılması da bu düşünceyi destekler niteliktedir. Düşünme baloncuğundaki cümle ile büyük kitaptaki kız çocuğu ilişkilendirildiğinde, bu kitaptaki uzun saçlı çocuğun, resmi çizen çocuğun kendisi olduğu söylenebilir. Ayrıca hikaye kitabındaki resmedilen çocukla kendisini resimlemiş olduğu kız çocuğu resmi çizen öğrencinin okuduğu kitapların arasında kendisini mutlu hissettiğini çok açık bir şekilde 
göstermektedir. Çünkü büyük çizilmiş ilk çocuk figüründe ağız belirgin olarak açık, mutlu; ikinci figürde ise ağız yukarıya doğru kıvrılmış mutlu yüz ifadesi şeklinde görülmektedir. Bunların yanı sıra çocuğun kendi isminin yazımında "CemRe" "R" harfinde gülümseyen yüz yapmış olması da bu tespitleri doğrulamaktadır.

\section{Duygu Durumlarının “Konuşma Baloncuğu” Figürleriyle İfade Edildiği Çizimlere İlişkin Bulgular}

Araştırmaya katılan öğrencilerin okurken hissettiklerine yönelik duygu durumlarının doğrudan ifade edildiği figürlerden biri “konuşma baloncukları"dır. Araştırmaya katılan öğrencilerin resimlerinde konuşma baloncuğuna yer verme sayıları ikinci sınıftayken sadece üç iken dördüncü sınıfta ise bu sayının yaklaşık olarak altı katı artarak 17'ye çıktığı belirlenmiştir. Bu baloncuklar aracılığıyla öğrencilerin en sıklıkla kitaplara ve okumaya dair duygularını yazılı olarak ifade ettikleri görülmektedir. İkinci sınıf öğrencileri okumaya dair duygularını "kalp şekli” (2CE-11) çizerek, "Kitap okumak mutluluk" (2GK-6) ve "Hoo çok keyifli” (2KK-8) şeklinde ifade ederken; dördüncü sınıf öğrencileri ise "Kitap Okumayı Çok Seviyorum / Bu Kitabı Okumayı Çok Seviyorum" (4DE-2), "A çokkomi-k bir kitap" (4DE20), "Çok şaşırdım acaba sonra ne olacak" (4GE-5), "Bu kitap çok heyecanlı" (4GE-19), "Hahahahahaha" (4GK-23), "ben bu kitabı çok sevdim hem kokulu hem eğlenceli" (4KK-26), "Kitabı çok sevdim" (4LE-10) şeklinde ifade etmiştir. Bununla birlikte dördüncü sınıf öğrencilerinden birisinin ise okuduğu eseri anlamsız bulduğunu belirtip çok net bir şekilde olumsuz bir değerlendirme yaparak eserin kendisini sıktığını şu şekilde dile getirdiği görülmektedir: "Sıkıldım anlamsız" (4GE-32).

Öğrencilerin ikinci sınıftayken konuşma baloncuklarında "kitaplara" dair herhangi bir açıklamaya yer vermediği belirlenmiştir. Ancak dördüncü sınıf öğrencilerinin ise kitaplara dair düşüncelerini "Çok kitap okumuş / uyuyor (4CE-6)", "Bu kitap çok güzel kafamda dünya kadar bilgi var. / Yaşasın! Kitaplar güzeldir!” (4GE-32), "çok güzel bir kitap” (4KE-13), "Bu kitap çok güzel” (4LK-6), "Bu kitap çok kötü” (4LE-10), "Bu kitabı hemen okumalıyım" (4LK-23) şeklinde ifade ettiği görülmüştür. $\mathrm{Bu}$ ifadelerin arasında "Bu kitap çok güzel... Yaşasın! Kitaplar güzeldir!” (4GE-32), şeklinde kitapları çok yücelten ifadeler olduğu gibi kitapla ilgili tahminlerin yürütüldüğü, bu tahminlerin doğrulandığı ve kitaptan duyulan memnuniyetle bir sonraki esere geçildiğinin haberinin verildiği "Güzel bir kitaba benziyor. Güzelmiş. Bir son-raki kitaba geçelim” (4KE-20), şeklinde ifadeler de görülmektedir. Diğer taraftan bir eseri anlamsız bulduğunu belirten öğrencinin bu eseri okurken hissettiğine dair duygu durumunu "Sıkıldım anlamsız" (4GE-32), şeklinde ifade ettiği belirlenmiştir.

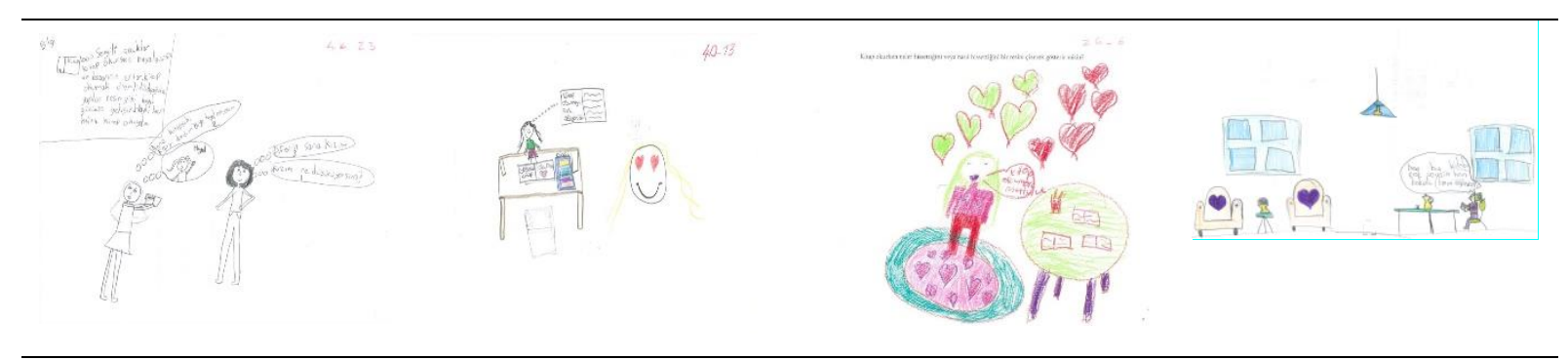


Resim 38'in (4KK-23) sol bölümünde üst köşede kare içinde "Bilgi" (bilgi notu olarak) kelimesinin yazılı olduğu görülmektedir. Bu karenin içine üzerinde "Kitap" yazılı olan bir açık kitap çizilmiştir. Bu kitaptan konuşma baloncuğu aracıllğıyla "Sevgili çocuklar Kitap okursanız hayal gücünüz ve başarınız artar. Kitap okumak önemlidir. Aşağıda yapılan resim gibi hayal gücünüz gelişir. Haydi, her hafta kitap okuyalım.” şeklinde düşüncelerini paylaşmışıtır. Baloncuğun dışında alt bölümde elinde "Şirin" yazılı açık bir kitap olan bir kız çocuğu görülmektedir. Bu kız çocuğunun başının üstündeki konuşma baloncuğunda "Anne kitaptaki kişiyi kendim diye hayal ediyorum" yazılmış ve bu baloncuk "2" olarak numaralandırılmıştır. Ayrıca bu baloncuğun altındaki düşünme baloncuğunun içinde bir kız çocuğu ile "Hayal" kelimesi yer almaktadır. Düşünme baloncuğunun yanında ă̆ız çizgisi yukarıya doğru olan bir kadın figürü bulunmaktadır. Bu kadının başının sağ üst yanında "Aferin sana kızım" yazılı olan konuşma baloncuğu yer almakta ve baloncuğun "3" sayısı ile numaralandırıldığı görülmektedir. Bu konuşma baloncuğunun altındaki bir başka konuşma baloncuğunun "1" sayısıyla numaralandırıldığ1 ve baloncukta "Kızım ne düşünüyorsun?" şeklinde bir sorunun yazıldığı görünmektedir. Resmin bütününe bakıldığında, çocuğun kitap okurken neler hissettiğine yönelik duygu durumunu annesiyle konuşarak ifade etmeye çalıştı̆ı anlaşılmaktadır. Çocuğun yüzünde çok belirgin bir mutluluk ifadesi olmamasına karşın düşünme/konuşma anını yansıtmak istediği ve hayal ettiği kahraman ile kendi yüz ayrımını ortaya koyabilmek için durgun yüz ifadesi çizdiği düşünülmektedir. Bilgi notunda ve düşünce/konuşma baloncuklarında sevgi kelimesine ve kitapları sevdiğine yönelik doğrudan kelime ya da cümle yer almamaktadır. Ancak annesinin ve hayal ettiği kahramanın belirgin bir şekilde gülümsüyor olması ve bilgi notuyla birlikte tüm düşünce baloncuklarındaki yazılı ve çizili ifadelerden, bu resmi yapan öğrencinin okuma eyleminden çok mutlu olduğu anlaşılmaktadır.

Resim 39'un bütününe bakıldığında merkezde bir masa önünde oturmuş, gözleri burnu olan, ăgzı yukarıya doğru kıvrımlı gülümseyen, uzun saçlı bir kız figürü görülmektedir (4DK13). Bu kız çocuğunun sağ tarafinda düşünce baloncuğunu işaret eden "Okumayı Çok Seviyorum" yazan ayrıca açık yazııı bir kitap çizilmiştir. Masanın üzerinde açık bir kitap bulunmaktadır ve kitabın bir sayfasında "Yaşasın kitap" diğer sayfasında "Okumak" ve bu yazının altında kırmızı bir "kalp" yer almaktadır. Masanın sağ bölümünde "Kitaplık" yazılı masaüstü bir kitaplık bulunmaktadır. Masanın yanında "emoji”" karakterinde uzun saçlı, gözleri "kırmızı kalp" şeklinde, ağzı yukarıya kıvrımlı gülümseyen bir baş görünmektedir. Kız çocuğun masa başında okuma eylemi içinde olması, açık kitaba "Yaşasın Kitap ve Okumak" ifadelerinin yazılması ve kırmızı bir "kalbin" çizilmiş olması sevgiyi işaret etmektedir. Masa üstünde "kitaplık" yazarak kitapların yer alması ve düşünme baloncuğunu açık yazılı bir kitap şeklinde çizerek "Kitap Okumayı Çok Seviyorum" yazması çocuğun okurken nasıl hissettiğini yazıyla da destekleyerek doğrudan açıklamak istediğini göstermektedir. Kız ve "emoji” yüzde, ağızların yukarıya doğru kıvrımlı bir şekilde gülümsemesi, "emoji” yüzün gözlerinin kırmızı renkli kalp şeklinde çizilmesi, çocuğun kitap okurken duyduğu sevgi düzeyini ve mutluluğunu açıkça paylaşmak istediğini göstermektedir.

Yukarıdaki üçüncü resimde (2GK-6), ağırlık olarak merkezden sağ tarafa yönelik bir kompozisyon oluşturulduğu görülmektedir. Yer çizgisi, kâğıdın bitişi, masa ve halı bu duruma göre konumlandırılmıştır. Yuvarlak masa üzerinde, üç açık ve yazılı kitap, içinde kalemler 
olan bir kutu yer almaktadır. Yerde yuvarlak elips şeklinde, renkli kalp desenleri olan bir yaygı/halı ve halının üzerinde uzun saçlı, kırmızı pantolonlu, kırmızı bluzlu bir kız çocuğu figürü çizilmiştir. Bu kızın ağız hizasına çok yakın "Kitap okumak mutluluk” şeklinde içinde yazı olan bir konuşma baloncuğu görünmektedir. Kız çocuğunun üst bölümünde, beş yeşil, beş de kırmızı renkte olmak üzere on kalp yer almaktadır. Masanın üzerindeki açık yazılı kitaplar, çocuğun her an okumaya hazır olduğunu gösterirken; yerdeki kalpli halı ve etrafındaki rengârenk kalpler de okuma eyleminden duyduğu büyük mutluluğu doğrular niteliktedir.

Yukarıdaki sonuncu resimde (4KK-26), yer çizgisi belli olan, iki penceresi, avizeli lambası olan bir oda içi resminin gerçekleştirildiği görülmektedir. Resmin sol bölümünde büyük ölçüde bir masa çizilmiş ve bu masanın yanında yeşil renkli bir sandalyenin üzerinde elinde resimli açık bir kitap olan kız çocuğu figürü resmedilmiştir. Bu çocuğun başının üzerinde "ben bu kitabı çok sevdim hem kokulu hem eğlenceli" yazılı olan konuşma baloncuğu yer almaktadır. Resmin bütününe bakıldığında, oda içindeki düzenden çocuğun kendisini çok iyi hissettiği ve okuma eyleminden çok hoşlandığı söylenebilir. Bunların yanı sıra çocuğun yüzünün yandan çizilmiş olmasına rağmen, ağızın yukarıya kıvrımlı görünüyor olması doğrudan bir göstergedir. Ayrıca konuşma baloncuğu aracılığıyla okuduğu ve tercih ettiği kitaba yönelik ipucu verirken; duygu durumunu da açıkça yansıtmaktadır.

\section{Duygu Durumlarının “Kitap velya Yazar Ísimleri” Aracılı̆̆ıyla İfade Edildiği Çizimlere Ilişkin Bulgular}

\section{Tablo 3}

Çizimlerde Yer Alan Eser ve Yazar İsimlerinin Dă̆ılımı

\begin{tabular}{|c|c|c|c|}
\hline \multicolumn{4}{|l|}{ Eser adı } \\
\hline İkinci Sınıf & Ö̆grenci & Dördüncü Sınıf & Ö̆grenci \\
\hline $\begin{array}{l}\text { ÇIKOLAT HIKAYESİ } \\
\text { "B,A,C,I,D,O,T"/ } \\
\text { "K,L,M,N,Ö,R,P” }\end{array}$ & $2 \mathrm{CE}-6$ & Sihirli Araba & 4CE-1 \\
\hline Sevgi Ağacı & $2 \mathrm{CK}-28$ & Uçmayı öğrendim & 4CE-4 \\
\hline Doktor Tavşan / Orman kitabı & 2GE-17 & $\begin{array}{l}\text { Saftirik / Saftirk / Saftirik / Wimpy Kid } \\
\text { SAFTİRİK (Gregin Günlüğü-TAM Bir Felaket) }\end{array}$ & $\begin{array}{l}4 \mathrm{CE}-4 \\
4 \mathrm{DE}-2 \\
4 \mathrm{DK}-8 \\
4 \mathrm{KE}-20\end{array}$ \\
\hline Masal & $2 \mathrm{GK}-33$ & Minecraft (ABCDEFgZŞdçöo) & 4CE-6 \\
\hline $\begin{array}{l}\text { İmparatorun okçuları } \\
\text { (Eğlenceli) / keloğlan ve kurt } \\
\text { (Sıkıcı) }\end{array}$ & $2 \mathrm{KE}-2$ & Çekmece Çekmece & 4CE-11 \\
\hline KÜÇÜK KUŞ & $2 \mathrm{KK}-6$ & SATRANÇ & 4CE-20 \\
\hline $\begin{array}{l}\text { Kara kedi / Kedi K1z / } \\
\text { Sindirella }\end{array}$ & $2 \mathrm{KK}-14$ & Rüzgar Kız & 4DK-6 \\
\hline Pamuk Prenses & $2 \mathrm{KK}-16$ & Bir köy var uzakta & 4DK-11 \\
\hline Kurşun Asker & $2 \mathrm{KK}-22$ & $\begin{array}{l}\text { Benim Adim ROnAlDO 1. Set / 2. Set / 3. Set / } \\
\text { 4. Set / Erkan işyeri }\end{array}$ & 4DE-19 \\
\hline $\begin{array}{l}\text { Peri / Peri / Gül } \\
\text { Gül Peri kendi mi? }\end{array}$ & $2 \mathrm{KK}-27$ & HAHA (A çok komik bir kitap) & 4DE-20 \\
\hline Tavşan & $2 \mathrm{KK}-28$ & 80 Günde Dünya Turu & 4GE-20 \\
\hline Kırmızı'nın büyük Keşfi & 2LK-12 & Küçük Prens & 4GE-34 \\
\hline
\end{tabular}




\begin{tabular}{llll} 
PUF PUF & 2LK-23 & Bu evde neler oluyor & 4KE-13 \\
ZELIŞ BANYO YAPIYOR & $2 \mathrm{MK}-3$ & Şarla-kom / Şarla-koms & 4KK-19 \\
Cesur toti & $2 \mathrm{MK}-12$ & Eğlence seti, Pamuk Prenses seti, Şip seti, & 4KK-22 \\
& & Düşünen çocuklar seti, Bilim seti, Keloğlan & \\
& & setleri, saftirik setleri, Şirin seti \\
Tekirden masallar & \multirow{2}{*}{$2 \mathrm{ME}-15$} & Şirin & 4KK-23 \\
& & Tatlı Ders & 4LK-15 \\
\hline Yazar adı & Yazar adı & 4CE-1 \\
\hline & Yazan Arda TURGUT imza: Arda T... & 4DE-19 \\
\hline
\end{tabular}

Araştırmaya katılan öğrencilerin hem ikinci sınıfta hem de dördüncü sınıfta resimlerinde yer verdikleri unsurlardan biri de öğrencilerin okudukları veya okumak istedikleri eserlerin isimleri olarak karşımıza çıkmaktadır. Bu eserlerin arasında hem yerli hem de çeviri eserler yer almaktadır. Eserler arasında çok bilinen Sindirella, Pamuk Prenses, Kurşun Asker, 80 Günde Dünya Turu, Sherlock Holmes, Küçük Prens gibi eserler olduğu gibi dört dördüncü sınıf öğrencisi tarafindan serideki farklı eserlerin belirtildiği Saftrik Greg'in Günlüğü adlı eser de yer almaktadır. Ayrıca dördüncü sınıf öğrencilerinden birinin (4KK-22) eserleri setler şeklinde (Eğlence seti, Pamuk Prenses seti, Şip seti, Düşünen çocuklar seti, Bilim seti, Keloğlan setleri, Saftirik setleri, Şirin seti) tek tek belirttiği görülmüştür. Bir de dördüncü sınıf ögrencilerinden ikisinin (4CE-1; 4DE-19) ise hem yazar hem de eser bilgilerini belirttiği belirlenmiştir.

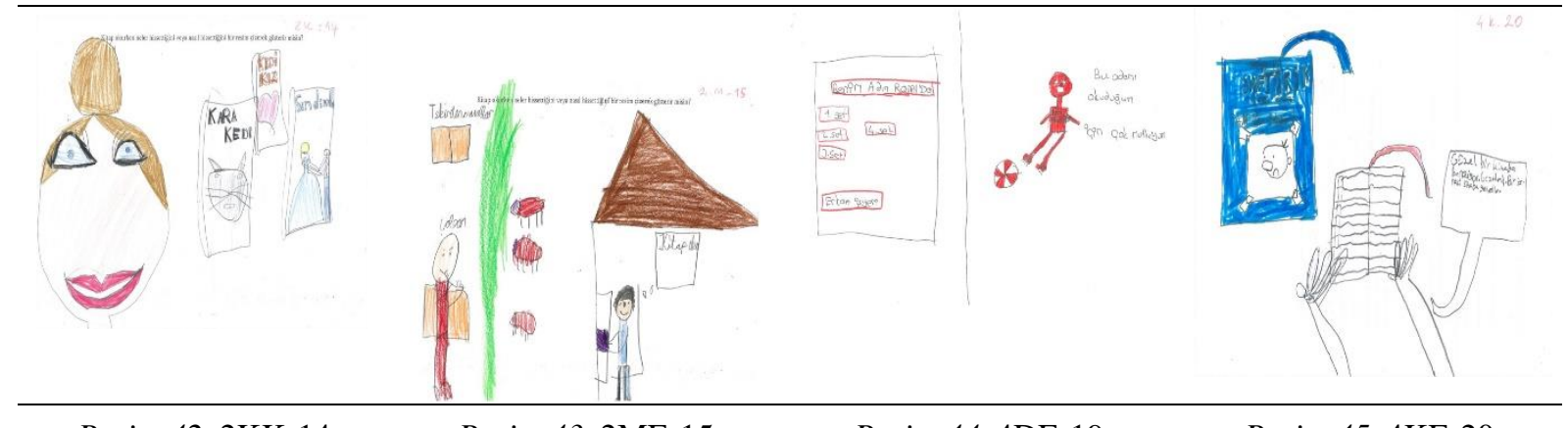

Resim 42. 2KK-14

Resim 43. 2ME-15

Resim 44. 4DE-19

Resim 45. 4KE-20

Resim 42'nin geneline bakıldığında (2KK-14), sol kısmında büyük bir kadın/çocuk portresi ve sağ kısmında güçlü derinlik algısıyla geriye doğru dizilerek resmedilmiş olan ü̧̈ kitap dikkat çekmektedir. Figürün topuzlu saçı, mavi gözleri, kırmızı dudakları olmasına karşın burnu yoktur. Kitapların her birinin üzerinde, o kitaba ait kitap kapağı bulunmaktadır. İçeriği ayrıntılı olarak gösteren kitap betimlemesi üç kitapta da görülmektedir. Birinci kitap "Kara Kedi" isminde, kedinin kara olarak çizildiği ve kitabın adının da kara renkte yazıldığı bir kitap, ikinci kitap, kapağında "Kedi Kız" yazıll, altında bir kalp çizilen bir kitap ve üçüncü kitap "Sinderella" adının yazılı olduğu, bunu betimleyen bir kadın ile bir erkek figürü çizildiği bir kitaptır. Bu öğrencinin resminden hangi tür kitapları okuduğu ya da tercih ettiği anlaşılmakta ve portrenin ağzı açık yukarı kıvrımlı şekilde belirgin olarak gülümsemesi, kitapları sevdiğini ve okurken mutlu olduğunu açıkça göstermektedir.

Resim 43'ün bütünü incelendiğinde sol tarafta "Tekirden Masallar" yazısı ve (2ME15), bu yazının altında açık olarak bir kitap biçimi görülmektedir. Onun alt kısmında ise kaval çalan çoban figürü ve bu figürün üzerinde "ç̧oban" yazısı dikkat çekmektedir. Aşağıdan 
yukarıya doğru çimende otlayan üç koyun görünmektedir. Burada öğrencinin okuduğu kitapları doğrudan yansıtma ve paylaşma isteği olduğu anlaşılmaktadır. Resmin sağ bölümünde, saydam çizilmiş çatılı bir ev içinde bir erkek figür yer almaktadır. Kısa siyah saçlı bu erkek, baştan aşağı düğmeleri olan bir iş önlüğü ya da formaya benzer uzun bir ceket giymiştir. Sandalyenin üzerinde oturan bu erkek figürün yüzü gülmekte ve elleri masanın üstündeki kitaba uzanmaktadır. Düşünme baloncuğu içinde "Kitap oku” ifadesi görülmektedir. Bunlara dayanarak öğrencinin kendisinin kitap okunmasının gerekli olduğunu düşündüğü ve bunu da eylem halinde göstermek istediği söylenebilir. Ayrıca isimleri belirtilen kitapları okuduğu ve bunların sevdiği kitaplar arasında olduğu söylenebilir. Ağzının yukarı kıvrımlı şekilde gülümsemesi, kitapla ilgilenmesi, düşünme baloncuğunun kitap biçiminde çizilmesi ve "Kitap oku" ifadesiyle bir öneride bulunması öğrencinin kitaba ve okumaya karşı olan mutluluğunu ve duyarlılığını açıkça ortaya koymaktadır.

Resim 44 incelendiğinde (4DE-19), kâğıdın bir çizgiyle ikiye bölündüğü; sol tarafında büyük dikdörtgen içinde "Benim adım RONALDO", "1.set, 2. set, 3. set 4 set" ve" Erkan işyeri” isminin yazılı olduğu bir kitap kapağ 1 görülmektedir. Çizginin sağ bölümünde, gözleri ve burnu olan, ağzı açık bir şekilde bütünüyle kırmızı renge boyanmış bir futbolcu figürü görünmektedir. Futbolcunun göğsünde "Real Madrid” yazmaktadır. Kolları iki yana açılmış ve krampon giymiş ayakları bir topa doğru yönelmiştir. Ayrıca futbolcunun sağ yanına "Bu adamı okuduğum için çok mutluyum” yazıldığı görülmektedir. Resmin geneline bakıldığında kitap ismini, set numaralarını ve yazar ismini yazarak ayrıntılı bir kitap betimlemesi yapmış olması; çocuğun bu kitabı çok severek okuduğunu ve bilincinde yer edindiğini göstermektedir. Bu kitabın ana karakterini ayrıntılı olarak betimlemesi gerçekte de var olan kitap kahramanını sevdiğini, takip ettiğini ve yazılı ifadesi de sevgi düzeyini göstermektedir. Ayrıca öğrencinin severek okuduğu bir kitap üzerinden örnek göstererek duygu durumunu doğrudan paylaştığı söylenebilir.

Resim 45'te sol bölümde (4KE-20), mavi renkte bir kare ve bu karenin içinde "Wimpy Kid, Saftirik Gregin Günlüğü Tam Bir Felaket” sözcüklerinin yazılı olduğu görülmektedir. Yazıların altında ayrıca bir kare, bu karenin içinde de bir portre yer almaktadır. Mavi karenin üst bölümünden dışarıya doğru kitap ayracı olduğunu düşündüren kırmızı renkte bir şekil görülmektedir. Resmin alt sınırından ortasına doğru, iki kol ve bu kolların arasında elle tutulmuş açık, yazılı, ayracı olan bir kitap bulunmaktadır. Kitabın sağ tarafında içinde "Güzel bir kitaba benziyor. Güzelmiş. Bir sonraki kitaba geçelim.” yazılı olan bir konuşma baloncuğu yer almaktadır. Resmin tamamında, duygu durumunu gösteren herhangi bir yüz ifadesi görülmemekle birlikte yazılı ifadelerden, bu öğrencinin kitapları ve kitap okumayı sevdiği açıkça anlaşılmaktadır. Sol taraftaki mavi karede adı yazılı olan eserin çocuğun en sevdiği kitaplar arasında bulunduğu söylenebilir. Nitekim konuşma baloncuğundaki ifadeler de bu durumu doğrulamaktadır.

\section{Tartışma}

Mevcut araştırmada çocukların okurkenki duygularını belirlemek ve bunu çizimler aracılığıyla ortaya koymakla çocukların okurken hissettiği duyguların tüm çıplaklığıyla ortaya konulması amaçlanmıştır. Uzun yıllar kütüphane öğretmenliği yapan ve Queensland Okul Kütüphaneleri Birliği tarafından Yılın En İyi Kütüphane Öğretmeni olarak ödüllendirilen 
Daley (2020, s. 175), aynı kitabı çocuklara ikinci veya üçüncü defa ya da daha fazla okuduğunda, okumanın bitiminde "kitap bize nasıl hissettiriyor?" diye soru sormaktadır. Bu soru ve diğer kitaplar hakkındaki sorulara verilen yanıtlar, çocukların okuma isteği ve sevgisine bir başka deyişle yaşam boyu okurlar olup olmamasına doğrudan etki edecektir. Çok kısa bir süre önce ortaokul öğrencileriyle yürütülen araştırmada 72 öğrenciden 37'sinin resminde insan figürü çizildiği belirlenmiştir. Bu resimlerden sadece ikisinde insanlar "asık suratll" olarak 35 resimde ise insanların mutlu ve güler yüzlü olarak çizildiği görülmüştür. Araştırmacılar bu durumu, öğrencilerin çoğunluğunun kütüphaneye karşı olumlu algıları olduğu şeklinde yorumlamıştır (Yılmaz ve Çakmak, 2020, s.758).

Çocukların okuma ve yazma ile ilgili duygu ve isteklerinin ilkokulda okuma ve yazmayı öğrenmedeki ilerlemeleri ile ilgili olabileceği ileri sürülmektedir (Francis, 1997, s.5). $\mathrm{Bu}$ iyi bir sınıf öğretiminde öğrenmenin duygusal boyutunu izleyebilmek için iyi bir durumdur. Okumanın beynimizden neler talep ettiğini ve düşünme, hissetme, çıarım yapma ve diğer insanları anlama yeteneğimize nasıl katk1 sunduğunu bilmek; okuyan beyinden giderek dijital hale gelen bir beyne geçiş yaptığımız bu günlerde bilhassa önemlidir (Wolf, 2017, s.13). Çizimler aracılığıyla ilkokul ikinci sınıf öğrencilerinin okurken hangi duyguları hissettiği yani okuma eylemi esnasındaki duyguları ve bu duyguların dördüncü sınıfa geldiklerinde değişip değişmediğinin belirlenmesi ve karşılaştırılması amacıyla yapılan araştırmanın bulguları, araştırmaya katılan öğrencilerin büyük çoğunluğunun hem ikinci sınıfta hem de dördüncü sınıftayken kitap okurken mutlu, keyifli, neşeli, sevinçli olduklarını başka bir deyişle olumlu duygular hissettiklerini göstermektedir. Bu duyguların kısa ve uzun vadede "okur" olma bakımından ne ifade ettiğine dair değerlendirmeler/çıkarımlar yapılması, ülkemizin gelecekteki okur profiline dair ışık tutacaktır.

Basılı materyaller yönünden zengin sınıf ortamları, çocukların okuryazarlık edinimini destekleyen ortamlardır (Wolfersberger, Reutzel, Sudweeks ve Fawson, 2004, s.213). Okurken mutlu hissettiği belirlenen öğrenci çizimlerinde bir sınıf veya okul kütüphanesi (2D9; 2D-13) olduğu söylenebilecek iç mekânlar görülmektedir. Bu yönüyle çizilen sinıf ortamında veya okul kütüphanesinde yer alan tüm çocukların mutlu olarak ifade edilmesi, onların okuma ortamı ve materyalleri bakımından gereksinimlerinin karşılandığı bir ortamda olduklarını ve yaptıkları aktivitelerin keyif verdiğini (Reyes ve Bishop, 2019, s. 276) göstermektedir. $\mathrm{Bu}$ araştırmada da, okuma ortamının konforlu olması ve çocukların ilgi duydukları eserlerle buluşturulmasının (Catapano, Fleming ve Elias, 2009, s.63) beraberinde çocukların okumaya olan sevgisini artırdığını, severek yaptıkları için de okurken kendilerini keyifli hissettiklerini göstermektedir. Bu unsurlar, okuryazarlığın gelişiminde etkili olan ortam boyutunun önemini ortaya koymaktadır (Guo, Justice, Kaderavek ve McGinty, 2012, s.308). Bu boyutlardan ilki sınıf düzeni ve okuryazarlık materyallerine erişimi kapsayan ortamın fiziksel boyutu; ikincisi ise öğretmenler ve çocuklar arasındaki okuryazarlık odaklı etkileşimleri kapsayan ortamın psikolojik boyutudur. Bu bağlamda, söz konusu çizimlerde sınıfta veya kütüphanede olumlu bir iklim oluşturulduğu görülmektedir.

Çocuklar her türlü olay örgüsünü severler, ancak en sevdikleri öyküleri tekrar tekrar duymak istemelerinin sebebi, karakter olarak anılan öykü kahramanlarına olan ilgileridir (Lukens, Smith ve Coffel, 2018, s.54). Çocuk kitaplarında, çocukların yeni yaşantılar kazanmalarına olanak sağlayan en temel öğelerden biri de öykündükleri kahraman/lar ve 
onların nitelikleridir. Okuduğu ya da dinlediği bir öykünün kahraman ya da kahramanlarıyla kurduğu etkileşim, çocuğun yeni düşsel arkadaşlar edinmesini sağlar (Sever, 2013, s.76-77). Araştırmaya katılan öğrenciler arasında özellikle de dördüncü sınıf öğrencilerinden bazıları kendilerini ana karakterin yerine koyacak şekilde (4KE-12) veya kendilerini yazdıkları eserlerin ana karakteri olacak şekilde (4K-5) kurgulamışlardır. Kendisini ana karakterin yerine koyan öğrenci (4KE-12) bu durumu "Oradaki insanların hislerine ortak olup onlar gibi oluyorum." şseklinde ifade etmiştir. Bu yaklaşım, onların okudukları eserleri ne kadar isteyerek okuduklarını, okurken kendilerini kaptıracak derecede odaklandıklarını gösterdiği gibi ilgi duydukları eserlere erişebildiklerini de göstermektedir. Kitaplarla bu şekilde ilişki kurulması, onların okumaktan zevk almalarını da sağlamaktadır (Pecrun, 2006 aktaran Zaccoletti, Altoè ve Mason, 2020, s.2). Kendini karakterin yerine koyan bu öğrencinin ikinci sinıftaki çizimi incelendiğinde, şema öncesi dönem özelliklerini sergileyen unsurlar olduğu görülmüştür. İkinci sınıfta araştırma verilerinin toplandığ 1 dönemde, bu öğrencinin hem okuma ve okuduğunu anlama düzeyi bakımından hem de okurken hissettiklerini çizimle ifade etmeye dair düzeyi bakımından veya başka herhangi bir nedenle sınıf düzeyinin gerisinde olduğu düşünülebilir ancak dördüncü sınıfta ise özellikle de okuma becerileri ve okurken hissettiklerine dair öylesine bir gelişim göstermiştir ki karakterlerin duygularına ortak olacak düzeye gelmiştir. $\mathrm{Bu}$ sonuç, hem öğrencinin iki yıldaki gelişimsel farkının ortaya konulmasının hem de gelişimsel farkların hangi düzeyde olabileceğinin belirli aralıklarla izlenmesinin hayati bir öneminin olduğunu göstermektedir.

Araştırmaya katılan öğrenciler ikinci sınıftayken öğrencilerden yalnızca birinin (2GE11) dördüncü sınıftayken ise yalnızca iki öğrencinin (4KE-16; 4KK-22) eser türlerini belirttiği görülmüştür. İkinci sınıf öğrencisi "roman, şiir, masal" türlerini yazarken dördüncü sınıf öğrencilerinden biri "hikâye, masal" türlerinin yanı sira "Ansiklopedi (sözlük)" sınıflandırması da yapmıştır. Dördüncü sınıf öğrencilerinden bir diğeri de (4KK-22), eserleri "Bilim Seti", "Keloğlan Setleri", "Saftirik setleri", "Şirin Seti”, "Eğlence Seti", "Pamuk Prenses Seti”, "Şıp Seti” ve "Düşünen Çocuk Seti” "setler” şeklinde sınıflandırmıştır. Bu eserler, kitapların rengârenk ve sınıflandırılmış olarak düzenli bir şekilde sıralandığı kitaplarla dolu bir kütüphane ortamında resmedilmiştir. Bu anlatımlar, bir yandan çocukların çok zengin bir okuma yelpazelerinin olduğunu ve okuma farkındalıklarının ne kadar üst düzeyde olduğunu gösterirken diğer yandan kendilerine hitap eden ve kişisel ilgi alanlarıyla ilgili olduğu kadar bilgi edinmelerine yardımcı olan kitapları da tercih ettiklerini (Edmunds ve Bauserman, 2006, s.417) göstermektedir.

Sayıları diğer çocuklar kadar olmasa da araştırmaya katılan çocukların bir kısmının ise okurken "çok mutlu” olduklarını "dişleri görünecek ve dilleri dışa sarkacak" derecede ağızları açık şekilde çizdikleri görülmüştür. Bu çocuklar birçok nedenle bu denli mutlu olabilirler. $\mathrm{Bu}$ nedenler arasında onların en çok sevdiği şeylerden birinin kitap okumak olması, kendi seçimleri doğrultusunda okudukları için bu seçimin onlara keyif vermesi ve/ya okudukları eserlerin çok eğlenceli olması sıralanabilir. Akal'a (2008, s. 12) göre çocuk kitaplarındaki hareketlilik ve değişkenliğin çocuğun doğal hareketli yapısı ve gelişimiyle koşut olması, çocuğun kitaplara ilgi duymasını sağlayarak kitaplarla çocukta pekiştirilen macera ve keyif arzusu, dünyayı ve kendini tanıma heyecanına dönüştürmektedir. Nitekim araştırmaya katılan öğrencilerden birinin eser adı belirterek (“Satranç”) figürü ăgzı kulaklarına varacak şekilde 
çizmiş olması, öğrencinin kitap okumayı çok sevdiğine işaret ettiği gibi kitabın ismini yazarak sevdiği kitaba yönelik bilgiyi de paylaşmak istediğini göstermektedir.

Şaşkın, heyecan, merak, korku, kızgın ve öfke duygu durumları, araştırmaya katılan öğrencilerden sadece dördüncü sınıf öğrencilerinden ikisinin çiziminde görülmüştür. Brechet, Bady ve Picard'ın (2009, s.601) gerçekleştirdikleri araştırmada, ya özel (zikzak ağız) ya da şaşkınlık ifadesiyle paylaşılan (ağız ve gözler tamamen açık) yüz ifadeleri aracılığıyla sekiz yaşından itibaren korkunun doğru bir şekilde tasvir edildiği belirlenmiştir. Belirtilen bu duygu durumlarının ifade edilmesinde, mevcut araştırmada çizimlerin yazılı ifadeler ve sembollerle desteklendiği tespit edilmiştir. Zambo'nun (2006, s.801) çalışmasında da çocuklar duygularını düşünme balonları aracılığıyla ifade ederken yazılı ifadelerin yanı sıra sembollere de yer vermiştir. Çizimlerde şaşkınlık ifadesi net bir şekilde ifade edilmesine karşın ne hissettiklerini açık bir şekilde ortaya koymak için öğrencilerin yazılı ifadeler ve sembollerden yardım alma gereksinimi duyduğu görülmektedir. Bunların yanı sıra "Çok şaşırdım acaba sonra ne olacak" ifadeleri ve "? ? ?" soru işaretleri bu öğrencilerin hangi konulara ve/ya türlere ilgi duyduğunu da göstermektedir. Bu şekilde öğrenciler bir nevi hissettiği duygunun nedenini açıklamak istemiştir. Nitekim çocuk kitaplarında konunun merak uyandırıcı, özgün ve keyifli olması gerektiği belirtilmektedir (Güzelyurt ve Saraç, 2018, s. 61). Bu düşünce aynı zamanda öğrencilerin çocuk yazınından nitelikli eserleri okuduğu şeklinde de yorumlanabilir.

Öğrenci çizimleri arasında kitaplara yönelik gözlemlerin de yansıtıldığı görülmüştür. Dördüncü sınıf öğrencilerinden birinin (4DK-15) çizdiği resimde, birbirine çok benzeyen iki kitap figürü görülmektedir. Ancak kitaplar arasında kitabın yeni ve temiz olmasıyla eğlenceli olması arasında; kitabın yırtık ve yıpranmış olmasıyla ise sıkıcı olması arasında bir ilişki kurulduğu görülmüştür. Bu sonuçlar, öğrencilerin kitapların yeni olmasından mutluluk duyduğunu gösterdiği gibi kitapların yıpranmış olmasından veya kitaplara yeterince özen gösterilmemesinden duyduğu üzüntüyü de yansıtmaktadır. Bunların yanı sıra eski ve yıpranmış kitaplar aynı zamanda sınıf kitaplığında yeni olarak nitelendirilebilecek ve çocuklar tarafından sevilen kitaplar olduğu gibi sınıf kitaplığında okunamayacak derecede yıpranmış kitapların da olduğunu düşündürebilir. Bu ayrım bir başka açıdan da çizimi yapan çocuğun kitaplara değer verilmesine dair farkındalık düzeyini de ortaya koymaktadır. Bu farkındalık beraberinde kitaplara dair duyarlılığı da artırmıştır.

Çizimlerde kütüphane ortamı resmedildiği gibi yatağın içinde elinde açık bir kitap tutan başını yastığa koymuş bir kız çocuğu, yastığın çevresinde "çok merak", "ediyorum", "Acaba ne olacak" şeklinde üç ayrı düşünce baloncuğu, üç raf ve bu raflarda rengârenk sıralanmış kitaplar, küçük çekmeceli dolabın üstünde biri açık diğeri kapalı renkli iki kitabın olduğu son derece zengin okuryazarlık ortamının anlatıldığı $(4 \mathrm{~K}-21)$ ev ortamları da resmedilmiştir. Bu durum öğrencinin okurken ne kadar iyi hissettiğini gösterdiği gibi çocuk yazını ile ne kadar güçlü bağlarının olduğunu da göstermektedir. Aynı zamanda okurken hangi duyguların yaşandığını net bir şekilde ifade etmek için yazıdan da yardım aldığını ortaya koymaktadır. Araştırmacılar çocuğun okuma-yazma öğrenmesiyle birlikte resimlerine yazının girdiğini bu nedenle onların bu heyecan ve isteklerinin kırılmaması için konuşan resimlerin engellenmemesi gerektiğini belirtmektedirler (Kırışoğlu, 2002 aktaran Buyurgan ve Buyurgan, 2007, s.138). 
Çizimlerde yüz ifadeleri bakımından "nötr" olarak nitelendirilebilecek figürler olmakla birlikte özellikle de kitap ve okumaya dair iç ve dış mekanda okunduğunu gösteren unsurlar olması ve okuma eyleminin ciddiyetle yapılması nedeniyle bu duygu ifadelerinin çocukların okumaya verdiği değeri gösterdiği düşünülmektedir. Öyle ki resimlerde rengârenk kitapların olduğu bir kütüphane ortamı, tüm masalarda kitapların açık olduğu bir sınıf ortamı, doğada bir ağacın altında ve yatağında "Minecraft" (yazarı Max Brooks, eserin sayfa sayısı 272) isimli eseri okuduğunu "Çok kitap okumuş" şeklinde ifade eden bir çocuk görülmektedir. $\mathrm{Bu}$ çizimlerden özellikle de sınıf ortamı dışında olanlar, okumanın öğrenciler için yaşamlarının ayrılmaz bir parçası haline geldiğini göstermektedir. Okumaya verilen değer, aynı zamanda okuma motivasyonunun önemli bileşenlerinden biri olarak görülmektedir (Merga ve Mat Roni, 2018, s. 135).

Öğrenci çizimlerinden birinde (4KK-16), kitaplarla dolu bir kütüphane ortamı yansıtılmıştır. Sağ bölümde, kat kat bölümlenmiş kitap raflart ve sol üst bölümde "Kütüphane" yazılı bir tabela bulunmaktadır. Öğrencinin kendisi olduğu düşünülen çocuk masada kitap okur durumdadır. Bu çocuğun yüzünün resmedilmemesi nedeniyle kitap okumaktan mutluluk duyup duymadığına yönelik bir duygu ifadesi anlaşılamamaktadır. Buna karşın kütüphane ortamında elinde bir kitap tutması, kütüphane yazısının renkli olarak vurgulanması, raflardaki kitapların rengârenk ve sınıflandırılmış olarak düzenli bir şekilde sıralanmış olması, resimdeki çocuğun kitap okumaktan keyif aldığını düşündürmektedir. $\mathrm{Bu}$ resimde kitap raflarındaki sıralama önemli bir bulgu olarak kabul edilebilir. Çünkü bu sıralama bir kütüphanedeki işleyişi göstermektedir. Öğrencinin sessiz bir ortamda kitap okumayı tercih ettiği ve kendi deneyimine dayanarak yer çizgisini de gösterdiği için belirgin bir kütüphane ortamını yansıtmak istediği söylenebilir. Ayrıca raflara bakılarak öğrencinin tercih ettiği türler hakkında da fikir edinilebilir. Bu örnekte olduğu gibi araştırmaya katılan öğrencilerin bir bölümü okurken ne kadar olumlu duygular hissettiklerini ve okumayla olan bağlarının gücünü göstermek için yüz ifadesi yerine kitaplara dair bir ortam betimlemeyi tercih etmiştir. Benzer şekilde ortaokul beşinci sınıf öğrencilerinin çizim ve anlatımlarıyla kütüphane algılarının belirlendiği araştırmada da, öğrencilerin tamamına yakınının kütüphane denildiğinde akıllarına gelen ilk şeyin kitap ve raf olduğu, kütüphaneye özellikle kitap okumak ve ders çalışmak için gittikleri, kütüphaneyi sessiz ve rahat bir ortam olarak gördükleri sonucuna ulaşılmıştır (Yılmaz ve Çakmak, 2020, s.744). Aynı çalışmada öğrencilerin yazılı anlatımlarında kütüphanenin en çok bilişsel, eğitimsel ve toplumsal yararlarına dikkat çekilirken, resimlerinde ise en çok mutluluk veren yer gibi psikolojik faydasına dikkat çekildiği belirlenmiştir. Bunların yanı sıra herhangi bir sınırlama getirilmeden yapılan serbest çizimler, bu araştırmaya katılan bir grup öğrencinin de yaptığı gibi çocukların olaylar hakkında daha fazla ayrıntıyı hatırlamalarına ve ifade etmelerine yardımcı olmuştur (Jolley, 2010 aktaran Barlow, Jolley ve Hallam, 2010, s.481).

Aerila ve Merisuo-Storm (2017, s.2486), önceki araştırmalara atıfta bulunarak okumaya olan bağlılık ve çocukların zevk için okumaya harcadıkları sürenin okuma başarılarıyla önemli ölçüde ilişkili bulunduğunu belirtmiştir. Diğer taraftan araştırmacılar, zayıf okuyucuların okumaktan hoşlanmadıklarını ve bu nedenle de okumaya akıcı okuyuculardan daha az zaman ayırdıklarını ileri sürmektedir. Mevcut araştırmaya katılan öğrencilerden şema öncesi dönemi yansitan çizimler (2DE-7; 2GE-27) yapan öğrencilerin 
zayıf okuyucular olduğu düşünülebilir. Okuma düzeylerinin düşük olması da onların okumaktan keyif almasına engel olabilir. Bu bağlamda gelecekte yapılacak araştırmalarda okuma isteksizliğinin ardındaki nedenlerin belirlenmesi ve bunların giderilmesine yönelik çözümler geliştirilerek uygulamaya geçirilebilir.

Araştırmaya katılan öğrencilerin bir bölümü, okurken hissettiği duyguları kalp figürleri aracılığıyla ifade etmişlerdir. Kalp figürleriyle ifade eden öğrenci sayısı dördüncü sınıfta azalmıştır. Ayrıca hem ikinci hem de dördüncü sınıfta kız öğrencilerin (kız: 28/20; erkek: 11/6) kalp figürlerine daha çok yer verdiği belirlenmiştir. Kalp figürleriyle, öğrencilerin okumaya dair sevgilerini göstermek istedikleri düşünülmektedir. Böylelikle öğrenciler, okurken ama okuduğunu anlayabildiği için ama okuduğundan keyif aldığ1 için mutlu olduklarını çizimleri aracılığıyla ifade ederken aynı zamanda okumaya dair duygularının ve bu duygularının ne kadar güçlü olduğunu kalp figürleriyle destekleme gereksinimi duymuşlardır. Ayrıca kalp figürlerinin "okul” la ilişkilendirildiği çizimler, çocukların okumaya dair olumlu duygular beslemelerinin kaynağında okullarının da olduğunu göstermektedir. Bu yönüyle olumlu bir okul ikliminin göstergelerinden birinin de okula dair sevgi olduğu düşünülebilir. Benzer şekilde kitap figürlerinin kalp figürleriyle desteklendiği durumlar da öğrencilerin kitaplarla aralarındaki güçlü bağları ve kitaplara olan sevgilerini göstermektedir. Okul ortamının yanı sıra ev ortamında da kalp figürlerinin olması, öğrencilerin evlerinde okumak için keyifli ve konforlu bir ortamlarının olduğunu okul ve ders dışında kendi istekleriyle okuduklarını göstermektedir. Bunların yanı sıra kitabın kalp şeklinde çizilmesi de öğrencilerin kitaplara duyduğu sevgiyi ve sevgisinin düzeyini yansitmaktadir.

Öğrencilerin okurken hissettiklerini kalp figürleri aracılığıly ifade etme oranları ikinci sınıftan dördüncü sınıfa geldiğinde azalırken "düşünme baloncuğu” aracılığıyla ifade etme oranlarının ise ikinci sınıftan dördüncü sınıfa gelindiğinde yaklaşık olarak üç katı arttığı belirlenmiştir. Bu durum öncelikle, yazılı olarak ifade etmedeki hâkimiyetin dördüncü sınıfa gelindiğinde ikinci sınıfa göre artması ile açıklanabilir. Bunun yanı sıra resimlerde anlatmak istediklerini destekleme ve okurken hissettiklerini net bir şekilde ifade etme gereksiniminden de kaynaklanabilir. Nitekim düşünme baloncuklarında yer alan ifadeler "mutlu, çok seviyorum, çok keyifli, çok iyi hissediyorum, kitabın içinde hissediyorum, okumak çok güzel" de bunu doğrulamaktadır. Diğer taraftan çizim konusunda öğrencilerin kendilerini yeterli görmedikleri veya çizimlerde okurken hissettiklerini net olarak yansıtamadığını düşünen öğrenciler de bu yolu tercih etmiş olabilir. 3-6.sınıf öğrencilerinin okuma hakkındaki duyguları ve algılarının düşünme baloncukları aracılığıyla toplandığı araştırmada da öğrencilerin duygu ve algılarını hem sözcükler, hem duygusal ifadeler hem de kalp figürleri gibi sembol ve soru işareti, ünlem işareti gibi noktalama işaretleriyle ifade ettiği görülmüştür (Zambo, 2006, s. 801). Bu sözcükler arasında "kolay, iyi, eğlenceli, gerçekten ilginç" sözcükleri, duygusal ifadeler arasında mutluluğu yansıtan "severim, hoşlanırım, çok mutlu, iyi hissederim" gibi olumlu ifadeler olduğu gibi hoşlanmama/anksiyeteyi yansıtan "üzgün, çok zor, yapamıyorum, berbat, yakmak istiyorum" gibi olumsuz ifadeler de yer almaktadır. Bir başka ifadeyle öğrenciler okuma hakkındaki duygu ve algılarını sembollerin yanı sıra sözcükler aracılığıyla ifade etme yolunu tercih etmiştir. 
Düşünme baloncuğunda olduğu gibi konuşma baloncuğu da ikinci sınıftayken çok az sayıda öğrencinin resminde yer alırken; dördüncü sınıfta ise neredeyse ikinci sınıfın altı katı kadar öğrencinin resminde görülmüştür. Cohn (2013, ss. 10-13), düşünme ve konuşma balonlarında duygusal ifadelere ve sembollere yer verildiğini belirtmektedir. Konuşma baloncuğunda öğrencilerden sadece biri "sıkıldığı"na dair olumsuz görüş belirtirken diğer öğrencilerin tamamı "olumlu duygular" ifade ederek özellikle de kitap sevgilerini dile getirmiştir. $\mathrm{Bu}$ durum öğrencilerin duygularını, kitaplarla olan bağlarını ve onlara dair düşüncelerini açık bir şekilde dile getirmek için konuşma baloncuklarındaki ifadelere başvurduğunu göstermektedir.

Araştırmaya katılan öğrenciler, hem ikinci hem de dördüncü sınıftaki resimlerinde, okudukları veya okumak istedikleri eserlerin isimlerine yer vermiştir. Bu eserlerin arasında hem yerli hem de çeviri eserler bulunmaktadır. İkinci sınıf öğrencilerinin belirttiği eserler arasında çok bilinen Sindirella, Pamuk Prenses, Kurşun Asker gibi eserler görülürken dördüncü sınıf öğrencilerinin belirttiği eserler arasında ise Küçük Prens, Saftrik Greg'in Günlüğü, 80 Günde Dünya Turu ve Sherlock Holmes gibi eserler yer almaktadır. Kitap isimlerine yer veren ikinci sınıf öğrencilerinden birinin kitap isminin yanı sıra onun "eğlenceli" veya "sıkıcı" olduğunu dahi resimde belirtme gereksinimi duyduğu görülmüştür. "Eğlenceli" olduğu belirtilen esere dair herhangi bir bilgiye ulaşılamamıştır. "sıkıcı" olduğu belirtilen eserin yayınevinin internet sitesi aracılığıyla ulaşılan tanıtım bilgilerinde ise eser için "Çocuklarımız, içimizden biri olan Keloğlan'ın serüvenlerini merakla ve heyecanla okuyacaklardır." açıklamalarının yapıldığı ayrıca eserin hayal gücü, değerler, dürüstlük ve dayanışma tema/değerlerini desteklediği ifade edilmiştir. Ancak eser hakkındaki bu açıklamalara karşın, ikinci sınıf düzeyinde bir öğrenci kitap okurken nasıl hissettiğini anlatmaya çalıştığı resminde eser adı vererek bir sınıflandırmaya gitmiş ve bu eseri "sıkıcı" bulduğunu belirtmiştir. Bu sonuçlar aynı zamanda ilkokul öğrencilerinin okur olarak eser içeriğine göre farklı duygular hissettiklerini göstermektedir. Bu hissettiklerinin arasında eser içeriğine dair öğrenci değerlendirmeleri onların okur yolculuğunun süresini de belirleyecek düzeyde önem taşımaktadır. Araştırma sonuçlarının ortaya koyduğu sonuçlardan biri de okunan eserlerin sevilmesiyle doğru orantılı olarak okuma sıklı̆̆ ve süresinin artmasıdır (Allington ve Gabriel, 2012, s.10). Bu sevgiyi etkileyen faktörlerden biri de eser seçimini öğrencilerin yapmasıdır. Hatta bu konunun etkisi veya önemi hakkında araştırmacılar şöyle söylemektedir: "Her çocuk okur, yeter ki eser/kitap seçimini o/kendisi yapsın". Öğrencilerin eser isimleri ve onların yanı sıra eserlere dair düşüncelerini (eğlenceli veya sıkıcı) belirtmeleri aynı zamanda Gambrel'in (2015, s.59) önceki araştırma sonuçlarına atıfta bulunarak okuma konusunda birbirine eşit iki önemli amaçtan biri olan "öğrencilerin okuma alışkanlığını geliştirmelerine yardımcı olunması” amacının bu öğrenciler için gerçekleştirildiğini de göstermektedir. Başka bir ifade ile bu öğrencilerin öğrenim gördüğü sınıflardaki öğretmenler, onlara okumayı öğretmekle kalmamış aynı zamanda onlarda okuma isteği de uyandırmıştır. Stratejik okumayı görselleştirmenin genç ergenler için ne anlama geldiğinin belirlenmesinin amaçlandığ bir araştırmada (Reyes ve Bishop, 2019, s. 274), duyguların ifade edilmesinde utanç, stres, can sıkıntısı, kızgınlık ve çaresizlik dahil 14 kod belirlenmiştir. Bazı çizimlerde öğrencilerin kafa karışıklığı, hayal kırıklığı ve ihanet duygularını resmettikleri görülmüştür. Mevcut araştırmaya katılan öğrenciler arasında ise ne ikinci ne de dördüncü sınıfta yaptıkları 
çizimler aracılığıyla okumaya dair böylesine olumsuz duygular hisseden öğrenci olmadığı düşünülmektedir.

\section{Sonuç ve Öneriler}

$\mathrm{Bu}$ çalışmada, öğrencilerin okurken hissettikleri duyguları belirlemek amacıyla görsel yaklaşım (Jensen ve diğerleri, 2007, s. 359) veya çizim yöntemine (Ward ve Shortt, 2013, s. 439) dayalı bir araştırma yürütülmüştür. Araştırmada katılımcılar nasıl hissettiklerini çizimler aracılığıyla ifade etmiştir. Böylelikle öğrencilerin öğrenmeleri ile ilgili olarak kendi duygularını keşfetmelerine firsat verilmiş ve nicel yöntemlerle kolayca yakalanamayan duygular (Ward ve Shortt, 2013, s. 439) ortaya çıkarılmıştır. Ayrıca okuma-yazma eğitimi araştırmalarında, öğrenci bakış açılarını anlamak için çizimin kullanımı konusunda çok az çalışma olsa da (Reyes ve Bishop, 2019, s. 264) mevcut araştırma ile veri toplama için sözel olmayan veya görsel yöntemlerin potansiyeline dikkat çekilmiştir.

Lewis ve Greene'e (1983) göre çoğu çocuk herhangi bir gerilim belirtisi göstermeden çizim yapmaktan hoşlanmaktadır ve bu yönüyle de çizimler, değerlendirme amaciyla kullanılabilecek güçlü bir araçtır. Bunların yanı sıra çocukların birçoğu soruları cevaplamayı sevmezken, çizim testleri ise hızlı, kolay ve eğlenceli bir şekilde tamamlanmaktadır (aktaran Farokhi ve Hashemi, 2011, s.2219). Bu yönüyle mevcut araştırmaya katılan öğrenciler arasında araştırmaya katılmak istemeyen hiçbir öğrenci olmadığı gibi öğrencilerin çizimleri de çok istekli olarak yaptıkları gözlemlenmiştir. $\mathrm{Bu}$ nedenlerle öğrencilerin okurken hissettiklerini çizimler aracılığıyla açık bir şekilde ifade edebildikleri düşünülmektedir. $\mathrm{Bu}$ bağlamda hem okumaya hem de kitaplara dair duyulan sevgi ve okurken hissedilen olumlu duygular aynı zamanda bu öğrenciler için ilkokulun ilk yıllarından itibaren okuma kültürü adına güçlü temeller atıldığını göstermektedir. Bu, hem ailelerin hem de okul idaresi ve öğretmenlerin çaba ve desteğini de ortaya koymaktadır. Ayrıca araştırma sonuçları, ilkokul öğrencileri için okuma konusunda kütüphane kavramı ve ortamının; okuma ortamlarının psikolojik boyutu bakımından öğretmen ve öğrenci arasında etkili iletişimin ve okuma materyallerinin çeşitliliği ile ulaşılabilir olmasının önemini göstermiştir. Diğer taraftan bu çalışmanın ilkokul öğrencilerinin okurken hissettikleri duyguların hangi yönde olduğunun ve bu duyguların değişip değişmediğinin değiştiyse bu değişimin hangi yönde olduğunun ortaya konulması bakımından ise ayrı bir önemi vardır. Ülkemizin 2003 yılından beri yer aldığ PISA (MEB, 2019 b, s. 41) sonuçları ve yakın geçmişte açıklanan ve ulusal PISA olarak adlandırılan ABİDE (MEB, 2019 a, s. 26) sonuçları okuma becerileri düzeyi açısından çok iç açıcı bir tablo ortaya koymamış olsa da mevcut araştırma sonuçları ilkokul öğrencilerinin okurken olumlu duygular hissettiklerini göstermektedir. $\mathrm{Bu}$ sonuçlar aynı zamanda araştırmaya katılan öğrencilerin büyük çoğunluğunun okuma kültürü ediniminde sağlam temellerinin olduğunu gösterirken diğer taraftan özellikle de okurken olumlu duygular hissetmeyen öğrencilerin izlenmesi ve bu duyguların olumlu yönde değiştirilebilmesi için atılabilecek adımların belirlenmesi ve uygulanması bakımından hayati önem taşımaktadır. $\mathrm{Bu}$ yönüyle alanyazında da belirtildiği gibi okuma-yazma becerilerinin öğrenilmesiyle birlikte öğrencilerin okurken nasıl hissettiklerinin belirlenmesine yönelik yapilacak değerlendirmelerle erken dönemde bu durumun olumlu yönde değişmesine yönelik önlemler alınabilecektir. Bu doğrultuda alınan önlemlerden biri de İlkokullarda Yetiştirme Programı 
(IYYP)'dır. Program ile Türkçe ve Matematik dersleri için belirlenen kazanımları edinemeyen öğrencilerin desteklenmesi amaçlanmaktadır (MEB, 2018, s. 1). Aş1 görevi görebilecek bu önlemlerle IYYEP benzeri iyileştirme programlarına duyulan gereksinim azalacağı gibi bu programlarda yer alan öğrenci sayısı da azalacaktır.

\section{Teşekkür}

Araştırmaya katılan öğrenciler ile araştırmaya destek olan okul idareci ve öğretmenlerine yürekten teşekkür ediyoruz. Bu vesile ile Ulusal Egemenlik ve Çocuk Bayramımızın 101. yılını kutluyor, Ulu Önder Atatürk ve onu bu yolda yalnız bırakmayan yurtseverlerimize şükranlarımızı sunuyoruz. Çalışmamızı Ulu Önder Atatürk ve Dünya Çocuklarına ithaf ediyoruz. Çalışmamızın ilk verileri herhangi bir yerde yayımlanmadı. Etik olarak iki veri grubunu bir arada ele almak istedik. Bu durum ve çalışma verilerinin resimlere ve bu resimlerin derinlemesine analizlerine dayanması nedeniyle metnin sayfa hacmi biraz uzun oldu. Saygilarımızla.

\section{Kaynakça}

Aerila, J. A. ve Merisuo-Storm, T. (2017). Emergent readers and the joy of reading: A Finnish perspective. Creative Education, 8(15), 2485-2500. https://doi.org/10.4236/ce.2017.815171

Akal, A. (2008) Eğitim-Sen çocuk ve gençlik edebiyatı ölçütleri için eleştiri ve öneriler. http://www.egitimsen.org.tr/down/cocuk_edebiyati_olcutleri.pdf.

Allington, R. L. ve Gabriel, R. E. (2012). Every child, every day. Educational Leadership, 69(6), 1015.

Applegate, A. J. ve Applegate, M. D. (2004). The Peter effect: Reading habits and attitudes of preservice teachers. The Reading Teacher, 57(6), 554-563.

Aydın Günbatar, S. (2019). Fenomenolojik araştırma (olgu bilim) yöntemi. H. Özmen ve O. Karamustafaoğlu (Yay. Hazl.), Eğitimde araştırma yöntemleri (ss. 293-316). Pegem Akademi.

Baker, L. ve Wigfield, A. (1999). Dimensions of children's motivation for reading and their relations to reading activity and reading achievement. Reading research quarterly, 34(4), 452-477.

Baker, L. Scher, D. ve Mackler, K. (1997). Home and family influences on motivations for reading. Educational psychologist, 32(2), 69-82.

Baker, L. Scher, D. ve Mackler, K. (1997). Home and family influences on motivations for reading. Educational Psychologist, 32(2), 69-82.

Barlow, C. M. Jolley, R. P. ve Hallam, J. L. (2011). Drawings as memory aids: Optimising the drawing method to facilitate young children's recall. Applied Cognitive Psychology, 25(3), 480487.

Bereiter, C. ve Bird, M. (1985). Use of thinking aloud in identification and teaching of reading comprehension strategies. Cognition and Instruction, 2(2), 131-156.

Brechet, C. Baldy, R. ve Picard, D. (2009). How does Sam feel?: Children's labelling and drawing of basic emotions. British Journal of Developmental Psychology, 27(3), 587-606.

Brechet, C. Picard, D. ve Baldy, R. (2007). Expression des émotions dans le dessin d'un homme chez l'enfant de 5 à 11 ans. Canadian Journal of Experimental Psychology, 61(2), 142-153.

Bruckerhoff, C. (1977). What do students say about reading instruction?. The Clearing House, 51(3), 104-107. 
Brown, H. D. (2000). Principles of language learning and teaching (C. 4). New York: Longman. https://d1wqtxts1xzle7.cloudfront.net/40433526/_H._Douglas_Brown_Principles_of_langua ge_learningBookZZ.org.pdf?

Buyurgan, S. ve Buyurgan, U. (2007). Sanat eğitimi ve ögrretimi. Pegem A Yayınc1lık.

Carlisle, J. F. (1995). Morphological awareness and early reading achievement. L. B. Feldman (Yay. Hazl.), Morphological aspects of language processing (ss. 189-209). Lawrence Erlbaum Associates, Publishers. https://books.google.com.tr/books?hl=tr\&lr=\&id=x4oK3rb27kC\&oi=fnd\&pg=PA189\&dq=Morphological+awareness+and+early+reading+achievement

Catapano, S., Fleming, J., ve Elias, M. (2009). Building an effective classroom library. Journal of Language and Literacy Education, 5(1), 59-73.

Causey, O. S. (Yay. Hazl.). (1955). What the colleges are doing in planning and Improving College Reading Programs; Selections from the first, second and third yearbooks of the southwest reading conference for colleges and universities. Texas: Texas Christian University Press. https://files.eric.ed.gov/fulltext/ED130220.pdf

Chard, D. J., Vaughn, S. ve Tyler, B. J. (2002). A synthesis of research on effective interventions for building reading fluency with elementary students with learning disabilities. Journal of learning disabilities, 35(5), 386-406.

Christensen, L. B., Johnson, B. ve Turner, L. A. (2015). Araştırma yöntemleri: Desen ve analiz. Anı Yayıncilik.

Clark, C. ve Foster, A. (2005). Children's and Young People's Reading Habits and Preferences: The Who, What, Why, Where and When. National Literacy Trust.

Clark, C., Osborne, S. ve Akerman, R. (2008). Young people's self-perceptions as readers. National Literacy Trust, 10, 1-63.

Cohn, N. (2013). Beyond speech balloons and thought bubbles: The integration of text and image. Semiotica, 197, 35-63. https://www.degruyter.com/document/doi/10.1515/sem-20130079/htmlhttps://doi.org/10.1515/sem-2013-0079

Coiro, J. ve Dobler, E. (2007). Exploring the online reading comprehension strategies used by sixth grade skilled readers to search for and locate information on the Internet. Reading Research Quarterly, 42(2), 214-257.

Creswell, J. W. (2017). Eğitim araştırmaları: Nicel ve nitel araştırmanın planlanması, yürütülmesi ve değerlendirilmesi H. Ekşi (Çev.). Edam.

Cunningham, A. E. ve Stanovich, K. E. (1997). Early reading acquisition and its relation to reading experience and ability 10 years later. Developmental Psychology, 33(6), 934.

Cunningham, A. E. ve Stanovich, K. E. (1997). Early reading acquisition and its relation to reading experience and ability 10 years later. Developmental Psychology, 33(6), 934.

Daley, M. (2020). Kitap okuyan çocuk yetiştirmek: Bir çocuğun okuma sevgisini nasıl beslersiniz? (M. Sır, Çev.). Orenda Kitap.

Dockett, S. ve Perry, B. (2005). Children's drawings: Experiences and expectations of school. International Journal of Equity and Innovation in Early Childhood, 3(2), 77-89.

Duke, N. K. ve Pearson, P. D. (2009). Effective practices for developing reading comprehension. Journal of Education, 189(1-2), 107-122.

Edmunds, K. M. ve Bauserman K. L. (2006). What teachers can learn about reading motivation through conversations with children. The Reading Teacher, 59(5), 414-424

Farokhi, M. ve Hashemi, M. (2011). The analysis of children's drawings: social, emotional, physical, and psychological aspects. Procedia-Social and Behavioral Sciences, 30, 2219-2224. 
Francis, H. (1997). Teaching beginning reading: a case for monitoring feelings and attitudes?. Reading, 31(1), 5-8.

Fuchs, L. S. Fuchs, D., Hosp, M. K. ve Jenkins, J. R. (2001). Oral reading fluency as an indicator of reading competence: A theoretical, empirical, and historical analysis. Scientific Studies of Reading, 5(3), 239-256.

Gambrell, L. B. (1996). Creating classroom cultures that foster reading motivation. Reading Teacher, 50, 14-25.

Gambrell, L. B. (2015). Getting students hooked on the reading habit. The Reading Teacher, 69(3), 259-263.

Ganasi, R. (2010). The reading experiences of grade four children [Yayımlanmamış doktora tezi, University of KwaZuluNata]. https:/lukzndspace.ukzn.ac.za/bitstream/handle/10413/1152/Ganasi_Romy_2010.pdf?sequence=1\&isAllo wed $=\mathrm{y}$

Gersten, R. Fuchs, L. S., Williams, J. P., ve Baker, S. (2001). Teaching reading comprehension strategies to students with learning disabilities: A review of research. Review of Educational Research, 71(2), 279-320.

Guo, Y. Justice, L. M. Kaderavek, J. N. ve McGinty, A. (2012). The literacy environment of preschool classrooms: Contributions to children's emergent literacy growth. Journal of Research in Reading, 35(3), 308-327.

Güzelyurt, T. ve Saraç, S. (2018). 48-66 aylık çocukların gelişim düzeylerine uygun çocuk kitapları nasıl olmalıdır? Bir Delphi çalışması. Uluslararası Çocuk Edebiyatı ve Eğitim Araştırmaları Dergisi (ÇEDAR), 2(1), 52-75.

Hallinger, P. Bickman, L. ve Davis, K. (1996). School context, principal leadership, and student reading achievement. The Elementary School Journal, 96(5), 527-549.

Harris, A. J. (1956). How to increase reading ability; a guide to developmental and remedial methods. Longmans and Green Co.

Harris, P. L. (1989). Children and emotion: The development of psychological understanding. Basil Blackwell Inc.

Hiatt, S. W. Campos, J. J. ve Emde, R. N. (1979). Facial patterning and infant emotional expression: Happiness, surprise, and fear. Child Development, 50(4), 1020-1035.

Hughes-Hassell, S. ve Rodge, P. (2007). The leisure reading habits of urban adolescents. Journal of Adolescent \& Adult Literacy, 51(1), 22-33.

Huss, E. ve Cwikel, J. (2005). Researching creations: Applying arts based research to Bedouin women's drawings. International Journal of Qualitative Methods, 4(4), 1-16.

Jensen, T. S. Voigt, J. R. Piras, E. R. ve Thorsen, B. R. (2007) Drawings as a link to emotional data A slippery territory. Reynolds M ve Vince R (Yay. Hazl.). Experiential learning and management education. Oxford University Press, 345-360. https://www.researchgate.net/publication/263587752_Drawings_as_links_to_emotional_data_ A_slippery_territory

Kearney, K. S. ve Hyle, A. E. (2004). Drawing out emotions: The use of participant-produced drawings in qualitative inquiry. Qualitative Research, 4(3), 361-382.

Kendrick, M. E. ve McKay, R. A. (2003). Revisiting children's images of literacy. Language and Literacy, 5(1), 1-9.

Kendrick, M. ve McKay, R. (2002). Uncovering literacy narratives through children's drawings. Canadian Journal of Education, 27(1), 45-60. 
Kendrick, M. ve McKay, R. (2004). Drawings as an alternative way of understanding young children's constructions of literacy. Journal of Early Childhood Literacy, 4(1), 109-128.

Lester, S. (1999). An introduction to phenomenological research. Taunton UK. https://www.researchgate.net/publication/255647619_An_introduction_to_phenomenological_ research

Lukens, R. J. Smith, J. J. ve Coffel, C. M. (2018). Çocuk edebiyatına eleştirel bir bakış (C. Pamay, Çev.). Erdem.

Mata, L. Mackaaij, M. J. ve Calado, M. (2020). Emotional responses to reading in the first grade-the "LER Cãofiante" Project. Psico-USF, 25(2), 321-330.

McKay, R. ve Kendrick, M. (1999). Young children draw their images of literacy. The Reading Professor, 22(1), 8-34.

McKenna, M. C. Kear, D. J. ve Ellsworth, R. A. (1995). Children's attitudes toward reading: A national survey. Reading Research Quarterly, 30(4), 934-956.

MEB. (2018). Millı̂ Eğitim Bakanlığı İlkokullarda Yetiştirme Programı Yönergesi. Millî Eğitim Bakanlığı Temel Eğitim Genel Müdürlüğü. http://tegm.meb.gov.tr/

MEB. (2019a). ABİDE akademik becerilerin izlenmesi ve değerlendirilmesi, 4.siniflar özet rapor. http://odsgm.meb.gov.tr/meb_iys_dosyalar/2019_06/27105534_ABYDE_4_2018_Ozet_Rapo r.pdf

MEB. (2019b). PISA 2018 Türkiye ön raporu. http://pisa.meb.gov.tr/wpcontent/uploads/2020/01/PISA_2018_Turkiye_On_Raporu.pdf

Merga, M. K., ve Mat Roni, S. (2018). Children's perceptions of the importance and value of reading. Australian Journal of Education, 62(2), 135-153.

Milligan, C. (2005). From home to 'home': situating emotions within the caregiving experience. Environment and Planning A, 37(12), 2105-2120.

Negi, R. (2015). Primary school childrens' constructions of literacy through drawings. Psychological Studies, 60(2), 204-214.

Patton, M. Q. (2018). Nitel araştırma ve değerlendirme yöntemleri (3. bs.) Bütün, M. ve Demir, S. B. (Yay. Hazl.). Pegem.

Pearson, P. D. ve Gallagher, M. C. (1983). The instruction of reading comprehension. Contemporary Educational Psychology, 8(3), 317-344.

Pehkonen, E., Ahtee, M. ve Laine A. (2016). Pupils' drawings as a research tool in mathematical problem-solving lessons. P. Felmer, E. Pehkonen, J. Kilpatrick (Yay. Hazl.), Posing and Solving Mathematical Problems (ss. 167-188.) Springer. https://link.springer.com/chapter/10.1007/978-3-319-28023-3_11

Pekrun, R. (2014). Emotions and learning. Educational Practices Series, 24(1), 1-31.

Perfetti, C. A. (1985). Reading ability. Oxford University Press.

Pressley, M. El-Dinary, P. B., Gaskins, I., Schuder, T., Bergman, J. L., Almasi, J., ve Brown, R. (1992). Beyond direct explanation: Transactional instruction of reading comprehension strategies. The Elementary School Journal, 92(5), 513-555.

Reyes, C. C. ve Bishop, P. A. (2019). What visualising strategic reading means for young adolescents. Journal of Visual Literacy, 38(4), 262-284.

Sever, S. (2013). Çocuk edebiyatı ve okuma kültürü̈. Tudem.

Share, D. L. (1995). Phonological recoding and self-teaching: Sine qua non of reading acquisition. Cognition, 55(2), 151-218. 
Sherif, C. W. Sherif, M. ve Nebergall, R. E. (1965). Attitude and attitude change: The social judgment-involvement approach. Philadelphia: W.B. Saunders Company.

Snow, C. (2002). Reading for understanding: Toward an $R \& D$ program in reading comprehension. Santa Monica, CA: Rand Corporation.

Stanovich, K. E. (1980). Toward an interactive-compensatory model of individual differences in the development of reading fluency. Reading Research Quarterly, 32-71.

Şahin Çakır, Ç. (2019). Gelişimsel araştırma yöntemi. H. Özmen ve O. Karamustafaoğlu (Yay. Hazl.), içinde Ĕgitimde araştırma yöntemleri (ss. 344-366.) Pegem Akademi.

TenHouten W. D. (2017) From primary emotions to the spectrum of affect: An evolutionary neurosociology of the emotions. A. Ibáñez, L. Sedeño, A. García (Eds.). Neuroscience and social science (ss. 141-167.) Springer. https://link.springer.com/chapter/10.1007/978-3-31968421-5_7

UNESCO. (2011). The Hidden crisis: Armed conflict and education; EFA global monitoring report. https://unesdoc.unesco.org/ark:/48223/pf0000191186

Valentin, K. M. D. ve Casipit, K. M. (2019). Challenges faced by teachers in teaching non-reader pupils. Salik-suri, 1(1), 59-68.

Wang, J. H. Y. ve Guthrie, J. T. (2004). Modeling the effects of intrinsic motivation, extrinsic motivation, amount of reading, and past reading achievement on text comprehension between US and Chinese students. Reading Research Quarterly, 39(2), 162-186.

Ward, J. ve Shortt, H. (2013). Evaluation in management education: A visual approach to drawing out emotion in student learning. Management Learning, 44(5), 435-452.

Wigfield, A. ve Guthrie, J. T. (1997). Relations of children's motivation for reading to the amount and breadth or their reading. Journal of Educational Psychology, 89(3), 420.

Wolf, M. (2017). Proust ve mürekkepbalığı: Okuyan beynin bilimi ve hikâyesi (F. B. Aydar, Çev.). Koç Üniversitesi Yayınları.

Wolfersberger, M. E. Reutzel, D. R. Sudweeks, R. ve Fawson, P. C. (2004). Developing and validating the Classroom Literacy Environmental Profile (CLEP): A tool for examining the "print richness" of early childhood and elementary classrooms. Journal of Literacy Research, 36(2), 211-272.

Yılmaz, M. ve Çakmak, N. (2020). Ortaokul beşinci sınıf öğrencilerinin yazılı anlatımlarında ve resimlerinde kütüphane algıları. Türk Kütüphaneciliği, 34(4), 744-772.

Zaccoletti, S. Altoè, G. ve Mason, L. (2020). Enjoyment, anxiety and boredom, and their controlvalue antecedents as predictors of reading comprehension. Learning and Individual Differences, 79 (101869), 1-11.

Zambo, D. (2006). Using thought-bubble pictures to assess students' feelings about reading. The Reading Teacher, 59(8), 798-803.

Ziegler, J. C. ve Goswami, U. (2005). Reading acquisition, developmental dyslexia, and skilled reading across languages: A psycholinguistic grain size theory. Psychological Bulletin, 131(1), 3. 